\title{
Analisis Kinerja Keuangan Bank Umum Syariah Sebelum dan Sesudah Pengalihan Dana Haji pada Bank Syariah
}

Financial performance analysis of Islamic commercial banks before and after transfer of hajj funds to Islamic banks

\section{Lisa Erliana Marwan}

Program Studi D4 Keuangan Syariah, Politeknik Negeri Bandung

E-mail: lisaerliana1997@gmail.com

\section{Iwan Setiawan}

Jurusan Akuntansi, Politeknik Negeri Bandung

E-mail: iwan.setiawan@polban.ac.id

\section{Ine Mayasari}

Jurusan Akuntansi, Politeknik Negeri Bandung

E-mail: ine.mayasari@polban.ac.id

\begin{abstract}
Government policy through UU No 34 Thn 2014 about Haij Fund Management said that the Haij Fund Management should with the principle of sharia. Then in 2014, there was a transfer Haij Fund from Conventional banks to Islamic banks. Hajj Fund that transferred to Islamic banks have a large value so it can give positive contribution to the financial performance such as DPK. The aim of this study was to find out the financial performance of 6 BPS BPIH before and after the transfer of Hajj Fund from conventional banks to Islamic banks. Taking case studies at PT. Bank Syariah Mandiri, PT. Bank BRI Syariah, PT. Bank BNI Syariah, PT. Bank Mega Syariah, PT. Bank Panin Dubai Syariah, and PT. Bank. Muamalat. The Data that used in this study is Return On Assets (ROA) and Financing to Deposit Ratio (FDR) in Quarterly Financial Report of 6 BPS BPIH,4 years before the transfer of haij fund that started 2010 until 2013, and 4 years after the transfer of hajj fund that started from 2015 until 2018. The method of data analysis in this study uses a different samples in non parametrik, which is Wilcoxon Signed Rank. Test. The result of this study shows us that there was a difference in ROA and FDR of BPS BPIH before and after the transfer of hajj fund from conventional banks to Islamic banks.
\end{abstract}

Keywords: return on aset, financing to deposit ratio, financial performance, baij fund, fund transfer

\section{Pendahuluan}

Indonesia merupakan negara dengan penduduk muslim terbanyak di dunia yaitu mencapai 225,25 juta jiwa atau sekitar 87,2\% dari keseluruhan jumlah penduduk Indonesia menganut agama Islam (CIA World Factbook:2018). Hal tersebut sebanding dengan bertambahnya calon jamaah haji di Indonesia setiap tahunnya. Maka untuk menyiasati bertambahnya calon jamah haji, pemerintah Arab Saudi memberikan porsi jamaah haji lebih banyak kepada Indonesia dibandingkan negara lainnya di dunia, sehingga Indonesia merupakan negara dengan porsi haji terbanyak di dunia. Hingga tahun 2017, jumlah masyarakat Indonesia yang mendaftar untuk mendapatkan kursi haji mencapai 3.305.207 orang, jauh melebihi kuota yang tersedia yaitu sebanyak 221.000 jamaah pada tahun 2017 (Data: Kementerian Agama RI). 
Meningkatnya akumulasi dana haji setiap tahunnya menjadi tantangan besar bagi pemerintah dalam merumuskan cara yang paling efektif dan efisien dalam pengelolaan dana haji. Pengelolaan dana haji tersebut harus dilakukan secara syariah, baik dalam tempat penyetoran dana haji maupun pengelolaan dan pemanfaatan dana yang sekaligus dapat memberikan keuntungan bagi jamaah haji dan pemerintah berupa adanya subsidi, penurunan Biaya Penyelenggaraan Ibadah Haji atau dengan Biaya Penyelenggaraan Ibadah Haji yang tetap, pelayanan dan sarana prasarana dalam penyelenggaraan ibadah haji harus lebih baik lagi kedepannya.

Dana haji yang dikelola oleh Direktorat Jenderal Penyelenggaraan Haji dan Umrah hingga tahun 2016, dana haji masih banyak ditempatkan di bank konvensional. Hal ini dibuktikan pada tahun 2013 dana haji yang dikelola oleh bank konvensional yaitu sebesar 20\% sedangkan bank syariah hanya mengelola 17\% sementara sisanya sebesar 63\% dalam bentuk sukuk (Data: Kementerian Agama RI). Dari fakta yang telah dipaparkan tentu saja sangat tidak relevan apabila dana haji yang diniatkan untuk ibadah, dicampur dengan sistem bunga yang dilarang oleh syariat islam. Akumulasi dana BPIH selama ini dikelola secara konvensional dengan ditempatkan di perbankan konvensional dan secara syariah dengan ditempatkan di perbankan syariah dan investasi di sukuk. Sudah seharusnya dana haji dikelola berdasarkan prinsip syariah karena dana tersebut diniatkan dan digunakan untuk ibadah haji.

Untuk menjawab persoalan tersebut, pada tahun 2014, pemerintah mengesahkan Rancangan Undang-Undang (RUU) Pengelolaan Keuangan Haji sekaligus mengalihkan penempatan dana haji dari bank konvensional ke bank syariah. Kementerian Agama RI melalui Dirjen Penyelenggaraan Haji dan Umrah (PHU) menetapkan Bank Penerima Setoran sdari enam Bank Umum Syariah dan sebelas Bank Umum Nasional yang mempunyai layanan syariah. Seluruh dana setoran haji yang disimpan di bank konvensional yaitu sebesar Rp 32 triliun secara bertahap dialihkan ke bank syariah (Sumber: Direktur Jenderal Penyelenggaraan Ibadah Haji dan Umrah dalam Detik Finance). Porsi pengelolaan dana haji yang dikelola bank syariah pun berbeda-beda. Pertumbuhan Dana Pihak Ketiga (DPK) perbankan syariah pun meningkat pada akhir tahun 2014. Peningkatan itu terjadi seiring dengan masuknya dana haji ke perbankan syariah per November 2014 sekitar Rp28 triliun. Kontribusi dana haji sekitar 14\% dari total DPK perbankan syariah (Sumber : Annual Report Bank Syariah Mandiri tahun 2014).

Adanya kebijakan pengalihan penempatan dana haji dari bank konvensional ke bank syariah dapat memberikan kontribusi positif untuk kinerja keuangan perbankan seperti DPK. Dengan adanya dana haji tersebut, diharapkan bisa membuat likuiditas bertambah dan meningkatkan pembiayaan. Dana haji yang masuk ke bank syariah akan membantu memperlonggar likuiditas bank yang selama ini ketat (Sumber: Direktur Bisnis BNI Syariah dalam Keuangan Kontan). Terutama bagi enam BUS yang menjadi BPS BPIH yaitu diantaranya Bank Mandiri Syariah, BRI Syariah, BNI Syariah, Panin Syariah, Bank Muamalat, dan Bank Mega Syariah.

Dari fenomena tersebutlah sangat penting untuk melihat bagaimana kinerja keuangan pada Bank Umum Syariah setelah mendapat pengalihan dana haji dari Bank Konvensional. Kinerja keuangan yang baik dapat mencerminkan kemampuan yang baik dari para pengelola atau pihak manajemen dalam mengelola keuangan dan memanfaatkan peluang secara maksimal sehingga menghasilkan return (imbalan) sesuai yang diharapkan. Kinerja keuangan sangatlah penting karena berkaitan dengan tujuan utama perusahaan dalam mencapai profit.

Kinerja keuangan yang akan digunakan dalam penelitian ini diukur dengan indikator profitabilitas dan likuiditas. Penyebab digunakannya indikator profitabilitas dalam penelitian ini, karena melihat dari tujuan utama didirikannya suatu perusahaan atau bank adalah memperoleh profit (Hijriyani \& Setiawan, 2017). Sehingga indikator profitabilitas merupakan indikator utama dalam mengukur kinerja keuangan. Sedangkan digunakannya indikator likuiditas karena kinerja keuangan bank tidak hanya dilihat dari kemampuan menghasilkan laba namun dilihat juga dari 
kemampuannya membayar kewajiban jangka pendek apabila tiba-tiba ditagih oleh nasabah atau pihak-pihak terkait.

Indikator profitabilitas dalam penelitian ini diukur dengan menggunakan rasio keuangan Return On Assets, karena ROA lebih memfokuskan pada kemampuan perusahaan untuk memperoleh pendapatan, dalam operasi pasar secara keseluruhan. Selain itu juga, dalam penentuan kesehatan bank, Bank Indonesia lebih mengutamakan nilai ROA daripada ROE, karena yang paling utama dari nilai profitabilitas suatu bank diukur dengan pencapaian laba oleh aset yang sebagian besar dananya diperoleh dari dana simpanan masyarakat. Sehingga ROA lebih mewakili dalam mengukur tingkat profitabilitas perbankan (Dendawijaya, 2001)

Kemudian indikator likuiditas diukur dengan menggunakan rasio keuangan yaitu Financing to Deposit Ratio, rasio tersebut untuk mengukur likuiditas suatu bank dalam membayar kembali penarikan dana yang dilakukan deposan dengan mengandalkan pembiayaan yang diberikan sebagai sumber likuiditasnya. Pengambilan rasio FDR dalam penelitian ini dikarenakan untuk melihat bagaimana kemampuan bank dalam mengelola Dana Haji yang masuk dalam bentuk Dana Pihak Ketiga yang dapat disalurkan dalam bentuk pembiayaan sehingga dana tidak menganggur.

Besarnya porsi pengelolaan dana haji oleh Bank Syariah tentunya berdampak pada kinerjanya. Dana haji yang masuk ke Bank Syariah dalam bentuk DPK, tentunya dapat memberikan kesempatan bagi bank untuk menyalurkan dana ke dalam bentuk pembiayaan. Pembiayaan yang disalurkan akan menghasilkan keuntungan yang dapat dilihat dari rasio ROA dan kemampuan bank dalam mengelola Dana Pihak Ketiga ke dalam bentuk pembiayaan sehingga dana tidak menganggur yang dapat dilihat dengan rasio FDR. Berdasarkan uraian yang telah dipaparkan, judul yang akan diangkat dalam penelitian ini adalah "Analisis Kinerja Keuangan Bank Umum Syariah Sebelum Dan Sesudah Pengalihan Dana Haji Pada Bank Syariah Periode 2010-2018 (Studi Kasus Di 6 BPS BPIH)".

Berdasarkan latar belakang rumusan masalah yang telah dijelaskan, dan ditarik bahwa tujuan penelitian ini yaitu untuk menganalisis kinerja keuangan sebelum dan sesudah pengalihan dana haji dan adakah perbedaan kinerja keuangan sebelum dan sesudah pengalihan dana haji dengan menggunakan indikator profitabilitas yaitu ROA dan indikator likuiditas yaitu FDR.

\section{Kajian Pustaka}

\subsection{Dana Haji dan Kinerja Bank Umum Syariah}

Kementerian Agama memiliki peran yang strategis dalam pengembangan keuangan syariah. Salah satu peran penting Kementerian Agama saat ini tercantum dalam Undang-Undang No. 34 tahun 2014 tentang Pengelolaan Keuangan Haji, telah dibentuk Badan Pengelolaan Keuangan Haji (BPKH) yang berfungsi sebagai pengelola dana setoran calon jamaah haji. Hal ini akan menjadi peluang bagi pengembangan industri keuangan syariah melalui penempatan dana haji baik di perbankan syariah, pasar modal syariah, maupun industri keuangan non-bank syariah. (Sumber:OJK)

Dengan adanya pengalihan penempatan dana haji dari bank konvensional ke bank syariah tentu saja akan menambah likuiditas serta jumlah Dana Pihak Ketiga (DPK) Bank Syariah khususnya 6 Bank Umum Syariah yang menjadi Bank Penerima Setoran (BPS BPIH). Karena sumber dana Bank Syariah meningkat, Bank Syariah dapat lebih optimal dalam memanfaatkan dana tersebut untuk ditempatkan pada pos-pos yang menghasilkan pendapatan bagi bank dan menyalurkan dana tersebut dengan produktif sehingga dapat menngkatkan profitabilitas. 


\subsection{Penelitian Terdahulu}

Penelitian ini dilakukan oleh Cahyono, dkk (2016) dengan judul "Impact of Government Policy on Hajj Funds Transfer on Conventional Bank and Islamic Bank. Third Party Funds in Indonesia: Difference in Difference Approach”. Hasil penelitian menunjukkan bahwa ada pengaruh yang signifikan antara kebijakan dari transfer dana haji dari bank konvensional ke bank syariah terhadap jumlah dana pihak ketiga yang dikumpulkan oleh bank konvensional dan bank syariah. Kebijakan pemerintah dalam dana Haji memiliki efek pada penurunan dana pihak ketiga yang dimiliki oleh bank konvensional dan kebijakan pemerintah dalam dan ibadah haji memiliki signifikan efek pada dana pihak ketiga di bank syariah. Perbedaan penelitian ini dengan penelitian sebelumnya yaitu dalam penelitian ini akan mengukur kinerja keuangan 6 Bank Umum Syariah yang menjadi BPS BPIH dan tidak memasukan bank konvensionnal sebagai sampel, variabel yang akan diteliti yaitu kinerja keuangan dalam bentuk rasio ROA dan FDR.

Penelitian yang dilakukan oleh Arini (2017) dengan judul 'Profitabilitas Sebelum Dan Sesudah Pengalihan Dana Haji Dari Bank Konvensional Ke Bank Syariah Periode 2011-2016 (Studi Kasus Di Bank Syariah Mandiri)". Hasil dari penelitian ini menunjukkan bahwa terdapat perbedaan profitabilitas Bank Syariah Mandiri sebelum dan sesudah pengalihan dana haji dari bank konvensional ke bank syariah, masuknya dana haji ke Bank Syariah Mandiri pada awal tahun 2014 menambah saldo Dana Pihak Ketiga bagi Bank Syariah Mandiri, dan meningkatkan keuntungan dari pembiayaan yang disalurkan. Perbedaan dari penelitian ini adalah dalam pengambilan sampel yaitu enam bank umum syariah yang menjadi BPS BPIH serta memasukkan variabel baru yaitu FDR.

Penelitian selanjutnya dilakukan oleh Firman (2016) dengan judul "Analisis Pengalihan Dana Haji dari Bank Konvensional ke Bank Syariah terhadap pertumbuhan Dana Pihak Ketiga (DPK) dan Penurunan Financing to Deposit Ratio (FDR) (Studi Kasus Di Bank Syariah Mandiri)”. Hasil dari penelitian ini adanya pengalihan dana haji tersebut bank tidak akan mengalami kesulitan dalam membayar kembali penarikan dana. Penurunan FDR menunjukan bahwa rasio likuiditas yang tinggi, dan dengan adanya pengalihan dana haji tersebut dapat menurunkan tingkat resiko likuiditas. Perbedaan dari penelitian ini adalah dalam pengambilan sampel yaitu enam bank umum syariah yang menjadi BPS BPIH serta memasukkan variabel baru yaitu ROA.

\subsection{Hipotesis Penelitian}

Kinerja keuangan bank dapat menggambarkan kondisi keuangan perusahaan pada suatu periode tertentu, baik menyangkut aspek penghimpunan dana maupun penyaluran dana. Dalam penelitian ini rasio keuangan yang digunakan adalah ROA dan FDR.

Ho : Tidak terdapat perbedaan tingkat ROA Bank Umum Syariah sebelum dan sesudah pengalihan dana haji dari bank konvensional ke bank syariah.

Ha : Terdapat perbedaan tingkat ROA Bank Umum Syariah sebelum dan sesudah pengalihan dana haji dari bank konvensional ke bank syariah.

Ho : Tidak terdapat perbedaan tingkat FDR Bank Umum Syariah sebelum dan sesudah pengalihan dana haji dari bank konvensional ke bank syariah.

Ha : Terdapat perbedaan tingkat FDR Bank Umum Syariah sebelum dan sesudah pengalihan dana haji dari bank konvensional ke bank syariah

\section{Metode Penelitian}

Metode penelitian yang digunakan yaitu deskriptif kuantitatif dengan pendekatan komparatif. Penelitian ini membandingkan kinerja keuangan pada enam BPS (Bank Dalam melakukan penelitian ini, maka dibutuhkan data laporan keuangan triwulan dari masing-masing enam BPS BPIH periode 2010-2018 yang menjadi objek penelitian. Sedangkan teknis analisiss data yang 
digunakan terdiri atas tiga tahapan, yaitu:

1) Uji Statistik Deskriptif

Hal pertama yang harus dilakukan yaitu yang berhubungan dengan pengumpulan dan peringkasan data. Statistik deskriptif sangat diperlukan karena data statistik yang diperoleh masih bersifat acak dan tidak tersusun dengan baik. Maka dari itu, data harus dirangkum dengan baik dan teratur agar dapat digunakan sebagai acuan untuk pengambilan keputusan. Statistik yang digunakan dalam penelitian ini adalah rata-rata (mean), maksimal, minimal, dan standar deviasi selama periode penelitian.

2) Uji Normalitas Data

Uji normalitas terhadap data dilakukan dengan menggunakan program SPSS yaitu ShapiroWilk untuk melihat apakah data terdistribusi secara normal atau tidak. Uji normalitas data menggunakan Shapiro-Wilk dengan menggunakan taraf signifikan 0,05. Dasar pengambilan kesimpulan dapat dilakukan berdasarkan probabilitas, yaitu :

a. Jika peluang $\mathrm{p}$ pada Test of Normality $>0,05$ disimpulkan bahwa data berdistribusi normal.

b. Jika peluang p pada Test of Normality $<0,05$ disimpulkan bahwa data tidak berdistribusi normal.

Jika data terdistribusi normal, pengujian hipotesis menggunakan Paired sample t-test, sedangkan data yang tidak terdistribusi normal, pengujian hipotesis menggunakan uji data berpasangan Wilcoxon Signed Rank. Test.

3) Uji Hipotesis

Uji hipotesis yang digunakan apabila data berdistribusi normal menggunakan uji Paired sample T-Test. Pengujian hipostesis Paired sample T-Test dilakukan terhadap dua sampel yang berpasangan (Paired). Namun, apabila data berdistribusi tidak normal menggunakan uji non parametrik yaitu Wilcoxon Signed Rank. Test. Wilcoxon Signed Rank. Test merupakan uji non parametrik yang digunakan untuk menganalisis data berpasangan karena adanya dua perlakuan yang berbeda (Pramana, 2012).

\section{Hasil dan Pembahasan}

\subsection{Analisis Deskriptif}

Hasil uji statistik deskriptif Pengalihan Dana Haji pada 6 Bank Umum Syariah dapat dilihat pada tabel dibawah ini :

Tabel 1. Statistik Deskriptif Pengalihan Dana Haji pada 6 Bank Umum Syariah Descriptive Statistics

\begin{tabular}{|l|r|r|r|r|r|}
\hline & N & \multicolumn{1}{|c|}{ Minimum } & Maximum & \multicolumn{1}{|c|}{ Mean } & \multicolumn{1}{|c|}{ Std. Deviation } \\
\hline ROA Sebelum & 90 & $-12,02$ & 4,13 & 1,3661 & 2,01486 \\
ROA Setelah & 90 & $-10,77$ & 4,86 &, 7364 & 1,43982 \\
FDR Sebelum & 90 & 66,39 & 255,89 & 97,7793 & 25,69116 \\
FDR Setelah & 90 & 68,70 & 99,11 & 86,5405 & 7,71272 \\
Valid N (listwise) & 90 & & & & \\
\hline
\end{tabular}

Sumber: Data sekunder yang diolah 2019

Berdasarkan pada tabel IV.3 jumlah data yang digunakan untuk penelitian ini adalah sebanyak 90 yang terdiri dari rasio ROA dan FDR pada saat sebelum dan setelah pengalihan dana haji ke bank syariah. Nilai minimum rasio ROA saat periode sebelum pengalihan dana haji yaitu sebesar 12,02 dan nilai maksimum sebesar 4,13. Nilai rata-rata sebesar 1,3661 dengan standar deviasi sebesar 2,01486. Sedangkan nilai minimum ROA pada periode setelah pengalihan dana haji adalah sebesar $-10,77$ dan tertinggi sebesar 4,86. Nilai rata-rata sebesar 0,7364 dengan standar 
deviasi sebesar 1,43982 .

Nilai minimum FDR pada periode sebelum pengalihan dana haji adalah sebesar 66,39 dan tertinggi sebesar 255,89. Nilai rata-rata FDR sebesar 97,7793 dengan standar deviasi sebesar 25,69116. Nilai minimum FDR pada periode setelah pengalihan dana haji adalah sebesar 68,70 dan tertinggi sebesar 99,11. Nilai rata-rata FDR sebesar 86,5405 dengan standar deviasi sebesar 7,71272 .

\subsection{Uji Normalitas}

Dalam penelitian ini menggunakan uji normalitas Kolmogrov Smirnov dan Shapiro-Wilk dengan menggunakan bantuan program SPSS 20 for Windows, dibawah ini merupakan hasil uji normalitas data :

Tabel 2. Uji Normalitas Data

\begin{tabular}{|l|r|r|r|r|r|r|}
\hline & \multicolumn{3}{|c|}{ Kolmogorov-Smirnov $^{\mathrm{a}}$} & \multicolumn{3}{|c|}{ Shapiro-Wilk } \\
\cline { 2 - 7 } & Statistic & \multicolumn{1}{c|}{ Df } & \multicolumn{1}{c|}{ Sig. } & \multicolumn{1}{c|}{ Statistic } & \multicolumn{1}{c|}{ Df } & \multicolumn{1}{c|}{ Sig. } \\
\hline ROA Sebelum &, 213 & 90 &, 000 &, 664 & 90 &, 000 \\
ROA Setelah &, 291 & 90 &, 000 &, 498 & 90 &, 000 \\
FDR Sebelum &, 268 & 90 &, 000 &, 635 & 90 &, 000 \\
FDR Setelah &, 079 & 90 &, $200^{*}$ &, 968 & 90 &, 024 \\
\hline
\end{tabular}

a. Lilliefors Significance Correction

*. This is a lower bound of the true significance.

Sumber: Hasil Olah Data SPSS 2019

Dari hasil uji normalitas data diatas dapat disimpulkan bahwa data pada saat sebelum dan setelah pengalihan dana haji pada bank syariah tidak terdistribusi normal karena nilai signifikansi < 0,05. Maka dari itu data yang tidak terdistribusi normal, pengujian hipotesis dilakukan menggunakan uji data berpasangan non parametrik Wilcoxon Signed Rank Test.

\subsection{Kinerja Keuangan Sebelum Pengalihan Dana Haji}

Berikut grafik perkembangan rata-rata ROA dan FDR pada 6 BPS BPIH, untuk menjadi acuan dalam menilai kinerja keuangan masing-masing bank.

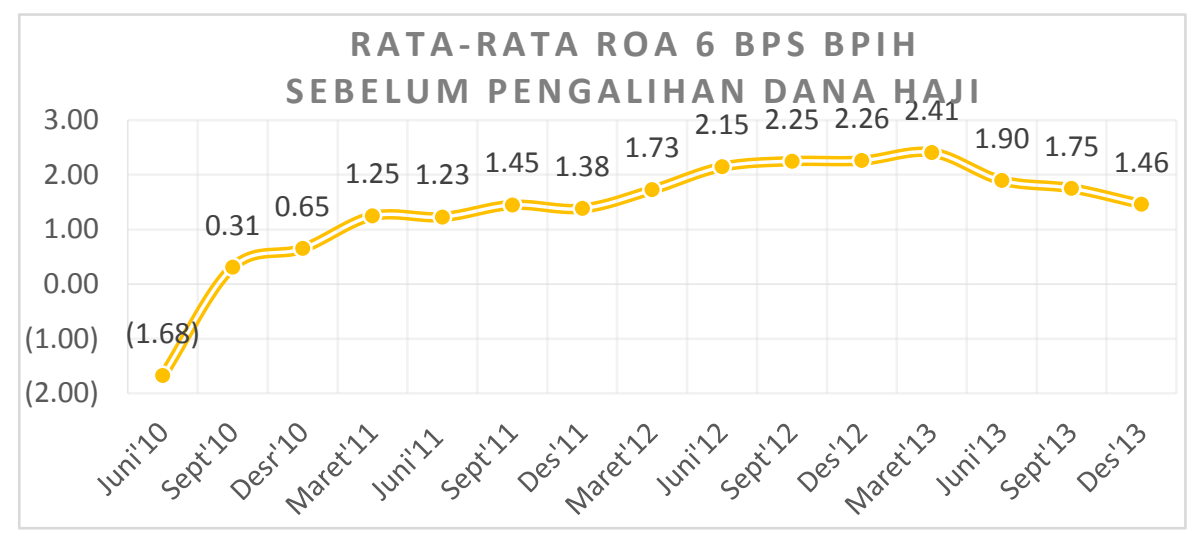

Gambar 1. Rata-rata ROA Sebelum Pengalihan Dana Haji Sumber: Hasil Olah Data Penulis 2019 
Berdasarkan gambar 1 diatas dapat diketahui bahwa di dalam perkembangan rata-rata Return On Assets (ROA) 6 bank syariah tersebut, terjadi kenaikan dari tahun 2010 dengan ratarata ROA berada pada posisi terendah lalu mengalami kenaikan hingga tahun Maret 2013. Namun setelah itu ROA mengalami penurunan di 3 triwulan terakhir di tahun 2013.

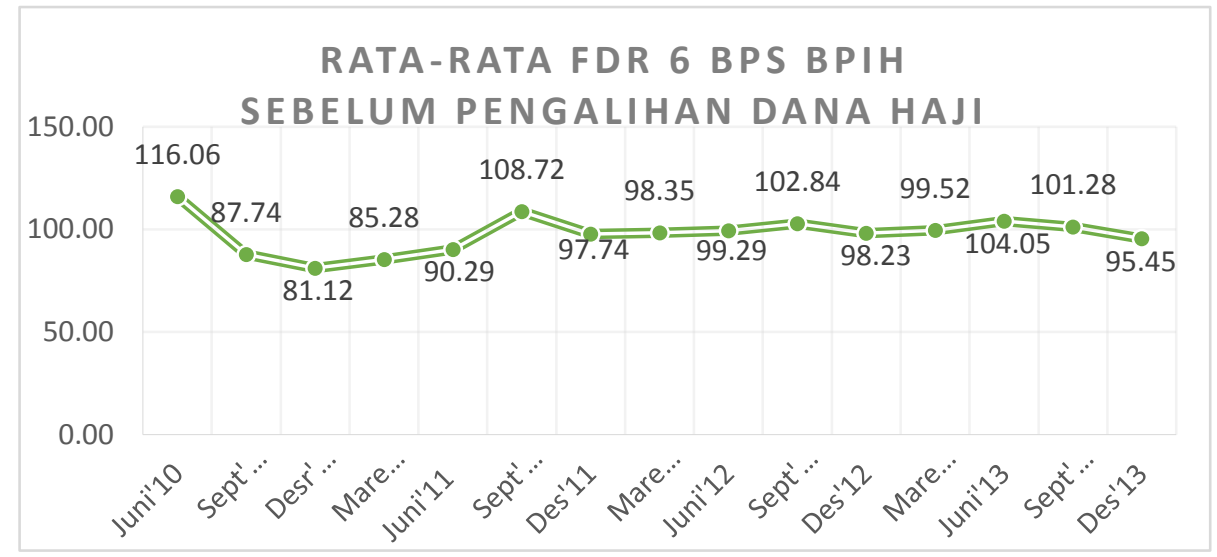

Gambar 2. Rata-rata FDR Sebelum Pengalihan Dana Haji Sumber: Hasil Olah Data Penulis 2019

Berdasarkan tabel 2 diatas dapat diketahui bahwa di dalam perkembangan rata-rata Financing to Deposit Ratio (FDR) 6 bank syariah tersebut, terjadi penurunan dari triwulan Juni hingga Desember 2010. Lalu mengalami peningkatan dari Maret 2011 hinga September 2011 dan harus mengalami penurunan kembali di Desember 2011. Selanjutnya mengalami fluktuatif hingga tahun 2013. Semakin tinggi rasio ini, semakin rendah kemampuan likuiditas bank sedangkan apabila rasio FDR menurun maka diindikasikan pembiayaan yang disalurkan oleh bank menurun dan dana yang berhasil dihimpun oleh bank belum bisa dikelola dengan optimal untuk segera disalurkan kepada masyarakat dalam bentuk pembiayaan.

\section{a. Kinerja Keuangan Sebelum Pengalihan Dana Haji PT Bank Syariah Mandiri}

Berikut disajikan grafik perkembangan dari masing-masing variabel penelitian selama periode pengamatan:

\section{ROA SEBELUM PENGALIHAN DANA HAJI BANK SYARIAH MANDIRI}

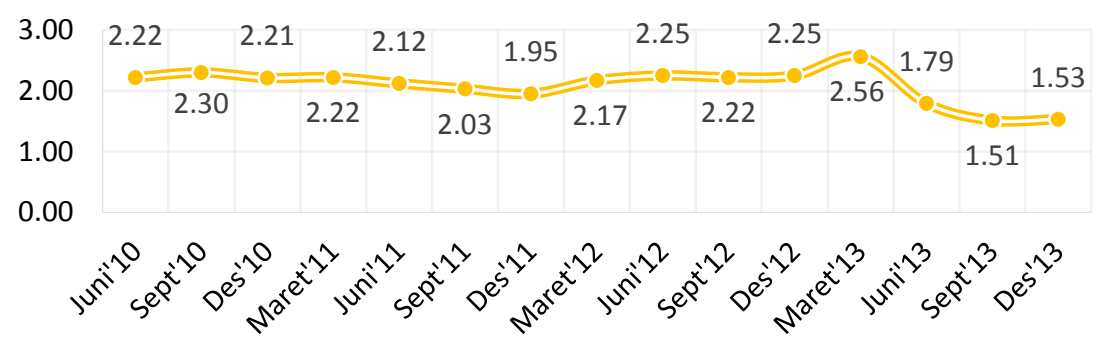




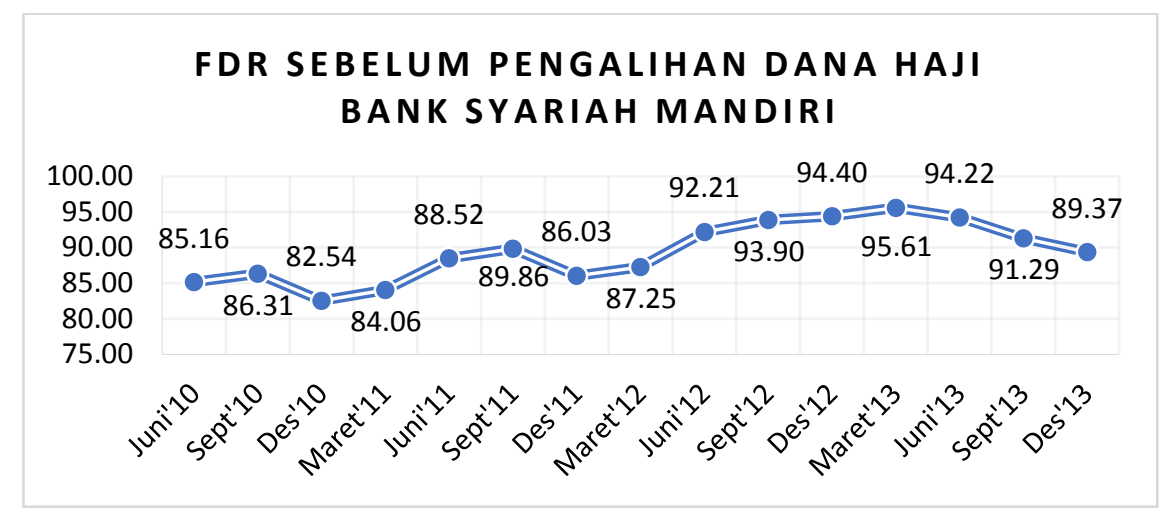

Gambar 3. Perkembangan ROA dan FDR Bank Syariah Mandiri Sumber: Hasil Olah Data Penulis 2019

\section{- Profitabilitas (Return On Assets)}

Dari tabel diatas terlihat bahwa ROA sebelum pengalihan dana haji pada Bank Syariah Mandiri cenderung stagnan mengalami sedikit penurunan dari triwulan ke 3 tahun 2010 hingga triwulan ke 4 tahun 2011. Lalu mengalami kenaikan kembali hingga Maret 2013 dan mengalami penurunan sampai Desember 2013. Apabila dilihat pada grafik IV.6, ROA Bank Syariah Mandiri sangat baik dan selalu berada pada peringkat pertama karena $>1,5 \%$. Bank Syariah Mandiri selalu berada di atas rata-rata dari tahun 2010 hingga September 2012 namun pada Desember 2012, Juni 2013, dan September 2013 nilai ROA berada di bawah rata-rata 6 BPS BPIH.

\section{- Likuiditas (Financing Deposit Ratio)}

Dari grafik diatas terlihat bahwa FDR sebelum pengalihan dana haji pada Bank Syariah Mandiri mengalami naik turun dari tahun 2010 hingga 2013. Apabila diperhatikan pada grafik 3, tingkat FDR Bank Syariah Mandiri masih berada pada standar yang ditetapkan Bank Indonesia, karena masih bisa menjaga ketentuan standar pada tingkat 78\%-100\%. Jika dibandingkan dengan grafik IV.3, FDR Bank Syariah Mandiri selalu berada di bawah rata-rata dari tahun 2010 hingga tahun 2013 kecuali pada Desember 2010 nilai FDR berada di atas rata-rata 6 BPS BPIH.

\section{b. Kinerja Keuangan Sebelum Pengalihan Dana Haji PT Bank Rakyat Indonesia Syariah}

Berikut disajikan grafik perkembangan dari masing-masing variabel penelitian selama periode pengamatan:

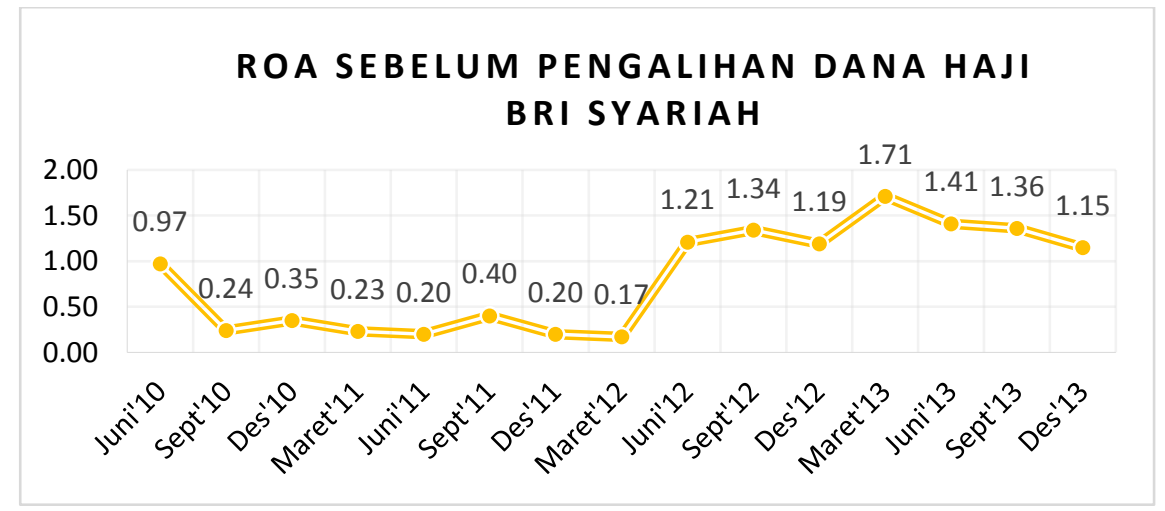




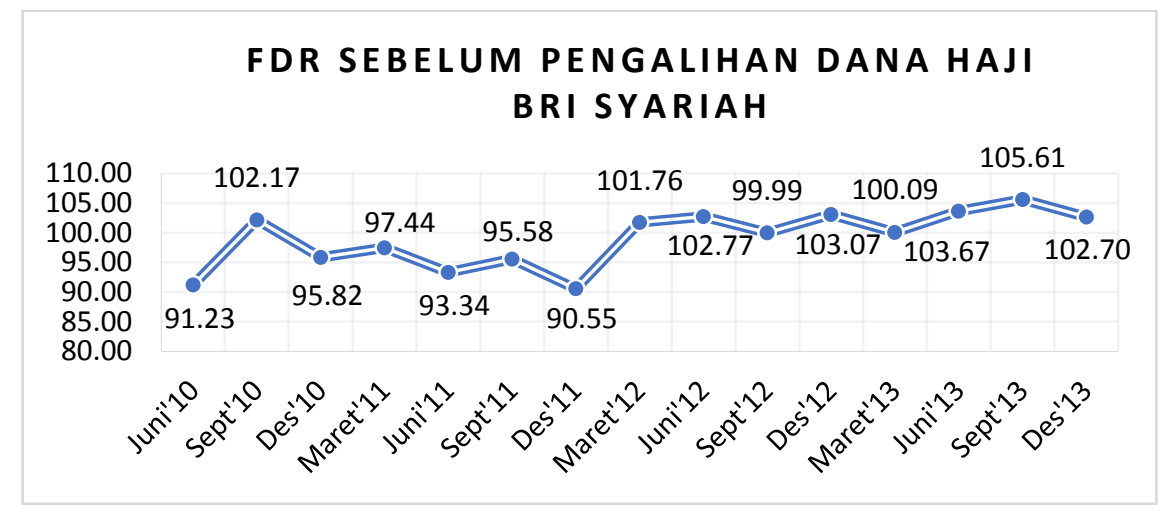

Gambar 4. Perkembangan ROA dan FDR BRI Syariah Sumber: Hasil Olah Data Penulis 2019

\section{- Profitabilitas (Return On Assets)}

Dari grafik diatas terlihat bahwa ROA sebelum pengalihan dana haji pada BRI Syariah mengalami penurunan tajam dari Juni 2010 ke September 2010 kemudian naik turun hingga Maret 2012. Kemudian naik tajam yaitu sebesar 1,04 di Juni 2012. Lalu mengalami kenaikan kembali di Maret 2013 dan mengalami penurunan sampai Desember 2013. Apabila dilihat pada grafik 4, ROA BRI Syariah untuk sebagian triwulan kurang baik karena $<0,5 \%$. Namun untuk triwulan berikutnya mengalami perkembangan ROA yang cukup baik. Jika dibandingkan dengan grafik IV.4, BRI Syariah selalu berada di bawah rata-rata dari September 2010 hingga Desember 2013.

\section{- Likuiditas (Financing Deposit Ratio)}

Dari grafik diatas terlihat bahwa FDR sebelum pengalihan dana haji pada BRI Syariah naik turun dari Juni 2010 hingga Desember 2011. Mengalami kenaikan di Maret 2012 yaitu sebesar 11,21. Lalu mengalami naik turun kembali sampai Desember 2013. Apabila diperhatikan pada grafik 4, tingkat FDR Bank Rakyat Indonesia Syariah sebagian triwulan masih berada pada standar yang ditetapkan Bank Indonesia, namun untuk sebagian triwulan lagi berada di atas 100\%. Hal tersebut mencerminkan banyak pembiayaan yang disalurkan, maka semakin il-liquid suatu bank. Jika dibandingkan dengan grafik IV.3, mengalami perkembangan yang fluktuatif, dimana terjadi peningkatan dan penurunan tingkat rata-rata FDR.

\section{c. Kinerja Keuangan Sebelum Pengalihan Dana Haji PT. Bank Negara Indonesia} Syariah

Berikut disajikan grafik perkembangan dari masing-masing variabel penelitian selama periode pengamatan

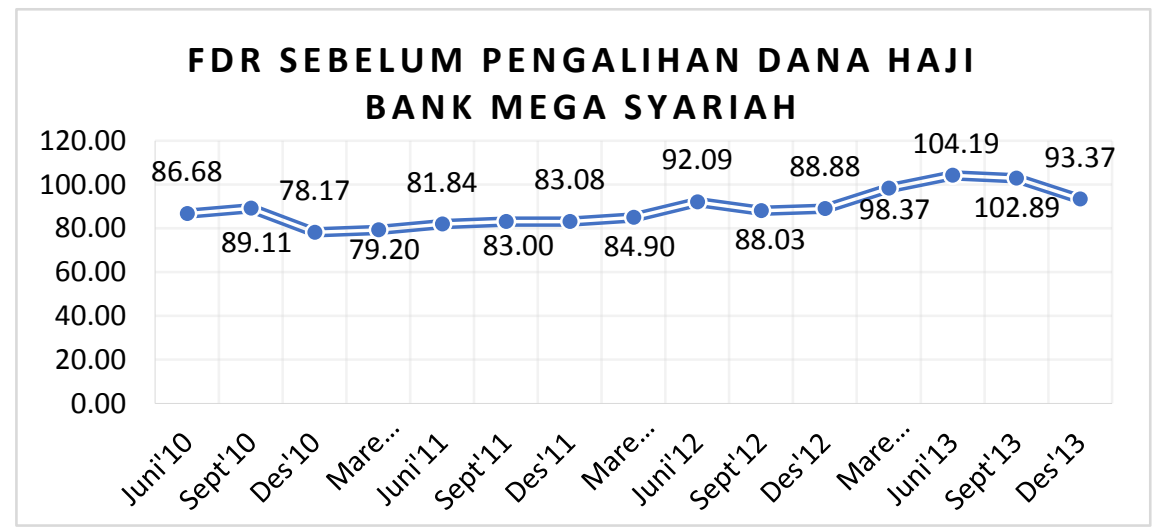




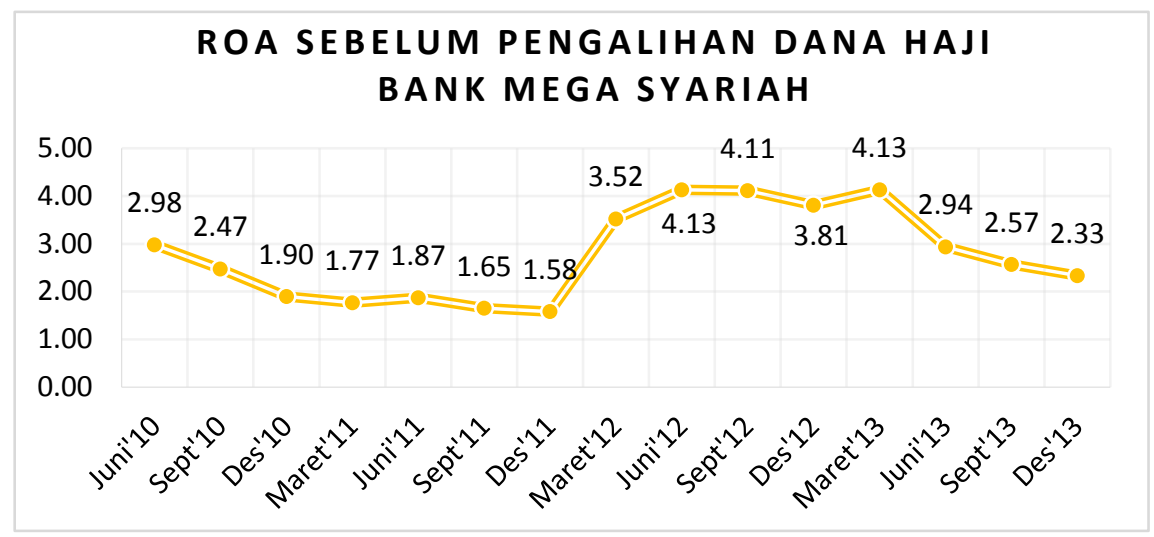

Gambar 5. Perkembangan ROA dan FDR BNI Syariah Sumber: Hasil Olah Data Penulis 2019

\section{- Profitabilitas (Return On Assets)}

Dari grafik diatas terlihat bahwa ROA sebelum pengalihan dana haji pada BNI Syariah mengalami kenaikan tajam pada Juni 2010 yaitu sebesar 11,37 ke September 2010 kemudian naik terus hingga Maret 2011. Kemudian stagnan sampai Desember 2013. Apabila dilihat pada grafik 5, ROA Bank Negara Indonesia Syariah untuk awal triwulan 2010 tidak baik karena $<0 \%$, hal tersebut membuat Bank Negara Indonesia Syariah sangat sensitif terhadap pengaruh negatif kondisi yang dapat membahayakan kelangsungan usaha. Namun untuk triwulan berikutnya mengalami perkembangan ROA yang sangat baik. Tetapi mengalami penurunan kembali untuk triwulan berikutnya. Jika dibandingkan dengan rata-rata ke enam BPS BPIH yang ada pada grafik IV.2, BNI Syariah selalu berada di bawah rata-rata 6 BPS BPIH. Namun pada pada tahun 2011 BNI Syariah berada di atas rata-rata 6 BPS BPIH.

\section{- Likuiditas (Financing Deposit Ratio)}

Dari grafik diatas terlihat bahwa FDR sebelum pengalihan dana haji pada BNI Syariah mengalami naik turun dari Juni 2010 hingga Desember. Apabila diperhatikan pada grafik 5, tingkat FDR Bank Negara Indonesia Syariah sebagian triwulan masih berada pada standar yang ditetapkan Bank Indonesia, namun untuk sebagian triwulan lagi berada di bawah 78\%. Hal tersebut mencerminkan banyak dana yang menganggur dan tidak disalurkan dalam bentuk pembiayaan. Jika dibandingkan dengan rata-rata 6 BPS BPIH, BNI Syariah selalu di bawah rata-rata 6 BPS BPIH.

\section{d. Kinerja Keuangan Sebelum Pengalihan Dana Haji PT Bank Mega Syariah}

Berikut disajikan grafik perkembangan dari masing-masing variabel penelitian selama periode pengamatan. 


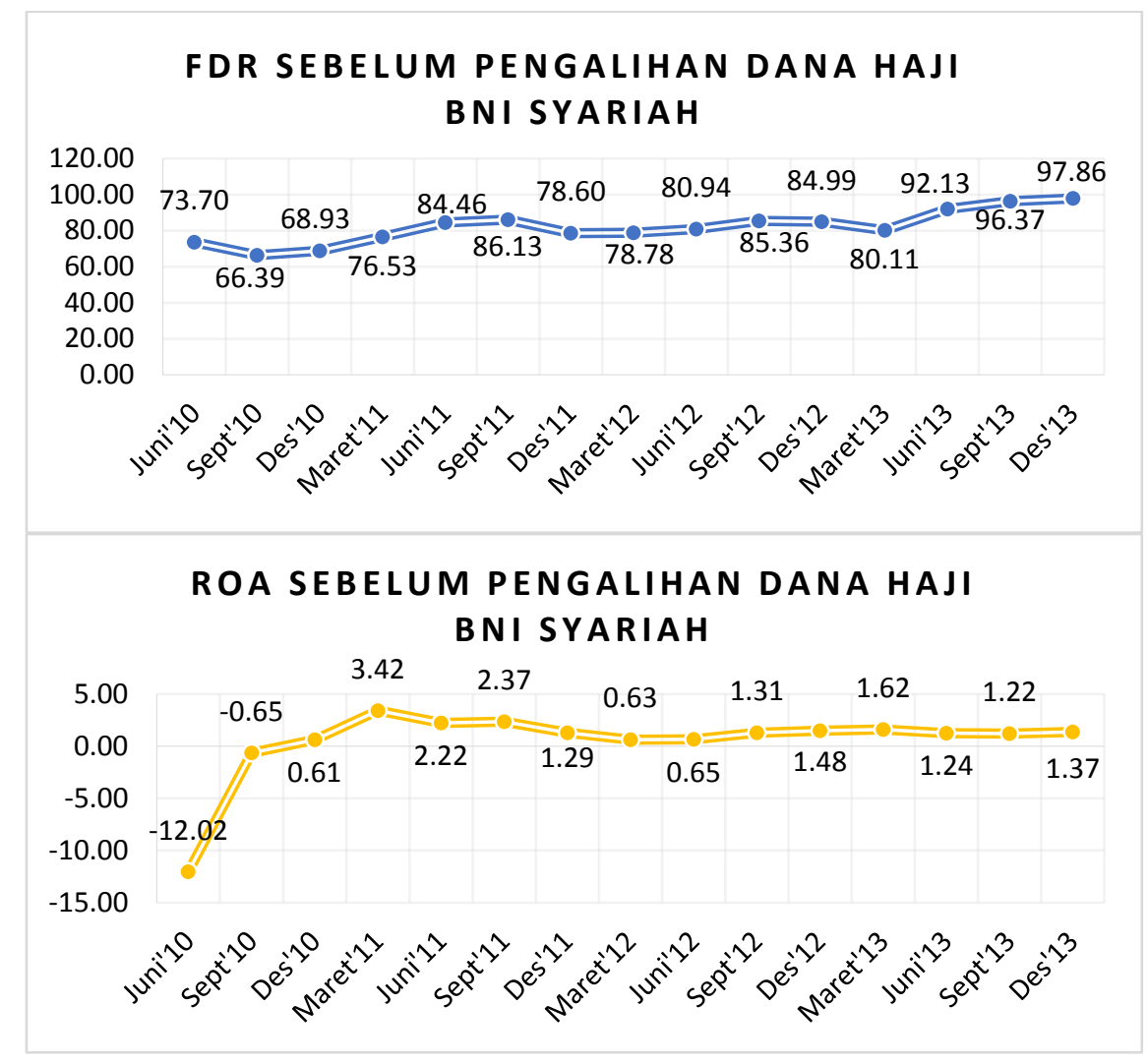

Gambar 6. Perkembangan ROA dan FDR Bank Mega Syariah Sumber: Hasil Olah Data Penulis 2019

\section{- Profitabilitas (Return On Assets)}

Dari grafik diatas terlihat bahwa ROA sebelum pengalihan dana haji pada Bank Mega Syariah mengalami penurunan hingga Desember 2011 kemudian mengalami kenaikan yang pesat sebesar 1,94 pada Maret 2012. Kemudian naik turun sampai Maret 2013 sampai akhirnya mengalami penurunan terus hingga Desember 2013. Apabila dilihat pada grafik 6 , ROA Bank Mega Syariah sangat baik dan selalu berada pada peringkat pertama karena $>1,5 \%$. Jika dibandingkan dengan rata-rata ROA ke 6 BPS BPIH, Bank Mega Syariah selalu berada di atas rata-rata 6 BPS BPIH.

\section{- Likuiditas (Financing Deposit Ratio)}

Dari grafik diatas terlihat bahwa FDR sebelum pengalihan dana haji pada Bank Mega Syariah mengalami naik turun dari Juni 2010 hingga Desember. Apabila diperhatikan pada grafik 6, tingkat FDR Bank Mega Syariah sebagian besar triwulan masih berada pada standar yang ditetapkan Bank Indonesia. Namun untuk 2 triwulan lagi berada di atas $100 \%$. Hal tersebut mencerminkan banyak pembiayaan yang disalurkan, maka semakin illiquid suatu bank. Jika dibandingkan dengan rata-rata FDR 6 BPS BPIH, Bank Mega Syariah selalu di bawah rata-rata 6 BPS BPIH. 
e. Kinerja Keuangan Sebelum Pengalihan Dana Haji PT Bank Panin Dubai Syariah

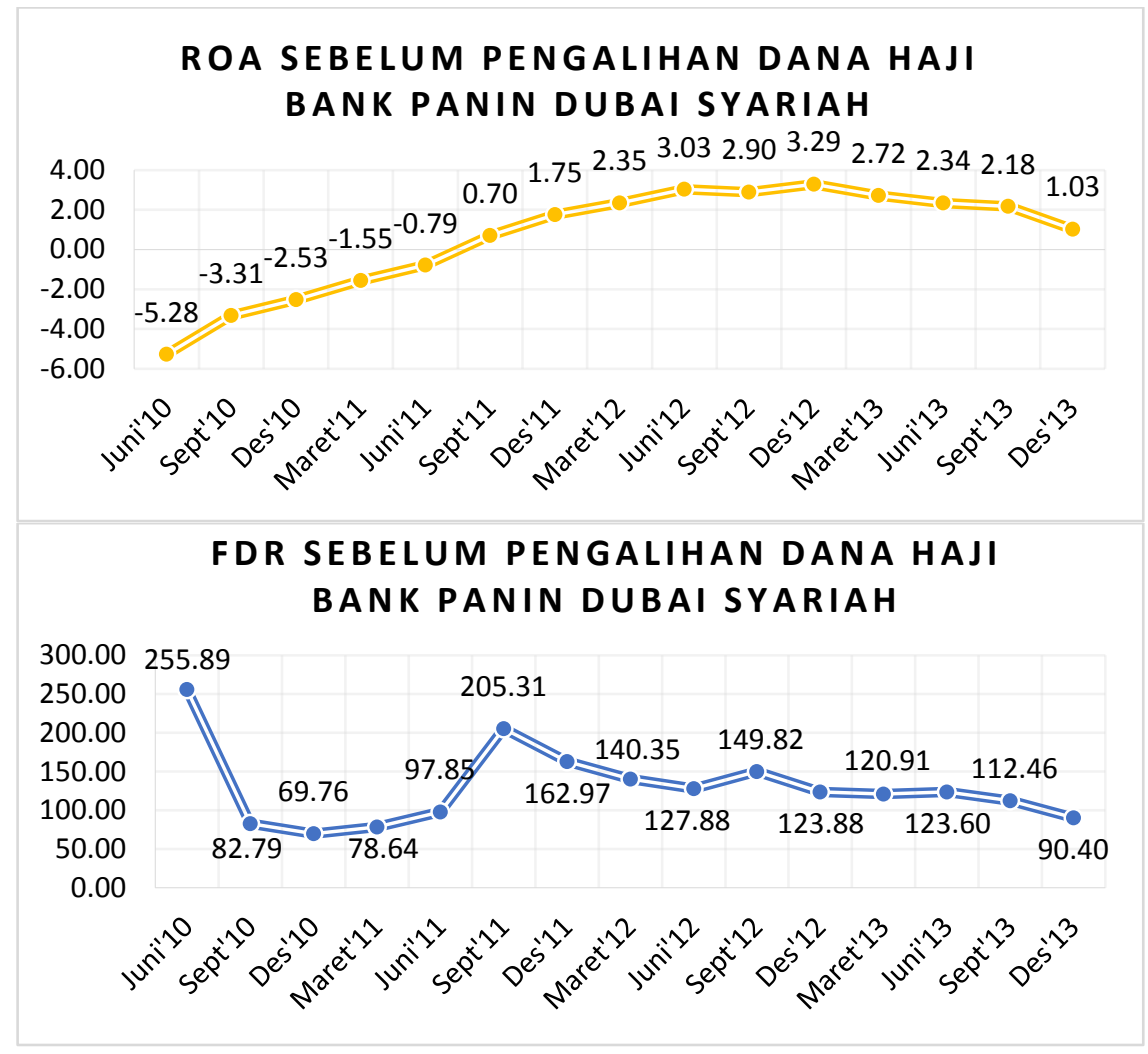

Gambar 7. Perkembangan ROA dan FDR Bank Panin Syariah Sumber: Hasil Olah Data Penulis 2019

\section{- Profitabilitas (Return On Assets)}

Dari grafik diatas terlihat bahwa ROA sebelum pengalihan dana haji pada Bank Panin Dubai Syariah bernilai negatif dan mengalami kenaikan terus menerus hingga Juni 2012 kemudian mengalami penurunan hingga kenaikan kembali. Namun harus kembali turun sampai Desember 2013. Apabila dilihat pada grafik 7, ROA Bank Panin Dubai Syariah untuk awal triwulan 2010 tidak baik karena $<0 \%$. Namun untuk triwulan berikutnya mengalami perkembangan ROA yang sangat baik. Tetapi harus mengalami penurunan kembali untuk akhir tahun 2013. Jika dibandingkan dengan rata-rata ke 6 BPS BPIH, mengalami perkembangan yang fluktuatif, dimana terjadi peningkatan dan penurunan tingkat rata-rata $\mathrm{ROA}$.

\section{- Likuiditas (Financing Deposit Ratio)}

Dari grafik diatas terlihat bahwa FDR sebelum pengalihan dana haji pada Bank Panin Dubai Syariah mengalami penurunan yang tajam yaitu sebesar 173,1 dari Juni 2010 ke September 2010. Kemudian naik turun hingga Juni 2011, dan kembali mengalami kenaikan yang cukup tinggi yaitu sebesar 107,46. Kemudian triwulan berikutnya mengalami penurunan kembali hingga Juni 2012, naik turun pada triwulan berikutnya kemudian stagnan sampai Juni 2013 hingga akhirnya mengalami penurunan sampai Desember 2013. Apabila diperhatikan pada grafik 7, tingkat FDR berada di atas 100\%. Adapun tingkat FDR yang di bawah 78\%. Jika dibandingkan dengan rata-rata 6 BPS BPIH, mengalami perkembangan yang fluktuatif, dimana terjadi peningkatan dan penurunan tingkat rata-rata dan FDR. 


\section{f. Kinerja Keuangan Sebelum Pengalihan Dana Haji PT Bank Muamalat}

Berikut disajikan grafik perkembangan dari masing-masing variabel penelitian selama periode pengamatan:

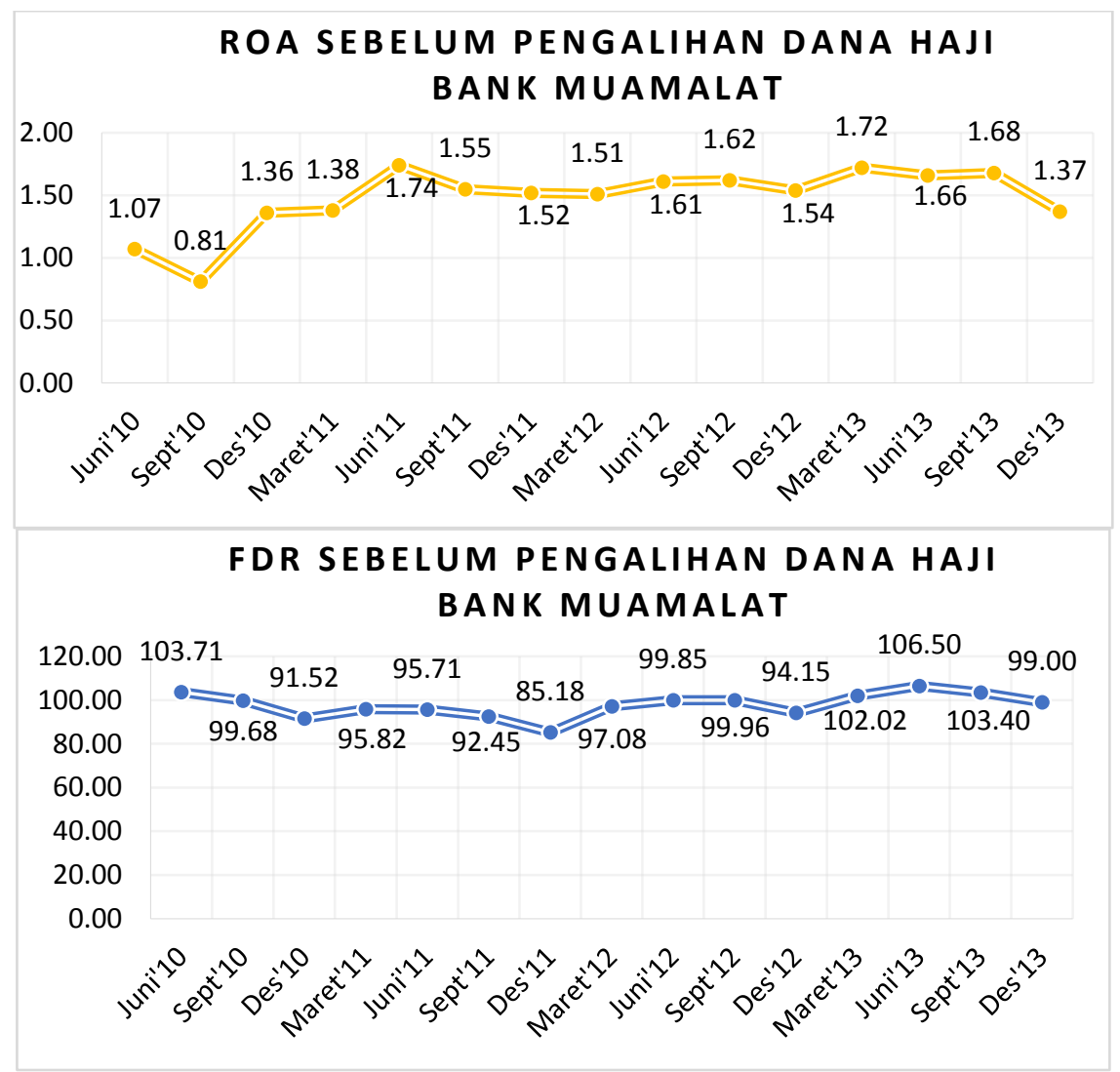

Gambar 8. Perkembangan ROA dan FDR Bank Muamalat Sumber: Hasil Olah Data Penulis 2019 (Gambar terlampir)

\section{- Profitabilitas (Return On Assets)}

Dari grafik diatas terlihat bahwa ROA sebelum pengalihan dana haji pada Bank Muamalat penurunan dari Juni 2010 ke September 2011 kemudian mengalami kenaikan hingga Juni 2011. Kemudian naik turun hingga Desember 2013. Pada tahun 2011 sampai September 2013 peringkat ROA sangat baik karena $>1,5 \%$. Tetapi harus mengalami penurunan kembali untuk Desember 2013. Jika dibandingkan dengan rata-rata ROA ke 6 BPS BPIH, mengalami perkembangan yang fluktuatif, dimana terjadi peningkatan dan penurunan tingkat rata-rata ROA.

\section{- Likuiditas (Financing Deposit Ratio)}

Dari grafik diatas terlihat bahwa FDR sebelum pengalihan dana haji pada Bank Muamalat naik turun dari tahun 2010 hingga tahun 2013. Apabila dilihat pada grafik 8 sebagian FDR ada pada tingkat $>100 \%$, maka tingkat likuiditas bank kurang baik. Jika dilihat pada grafik dibandingkan dengan rata-rata 6 BPS BPIH, Bank Muamalat mengalami mengalami perkembangan yang fluktuatif, dimana terjadi peningkatan dan penurunan tingkat rata-rata FDR.

\subsection{Kinerja Keuangan Setelah Pengalihan Dana Haji}

Sebelum mengetahui kinerja keuangan masing-masing bank. Dilakukan pengambilan ratarata untuk ROA dan FDR agar menjadi acuan dalam penilaian kinerja keuangan masing-masing 
bank. Berikut grafik perkembangan rata-rata ROA dan FDR pada 6 BPS BPIH

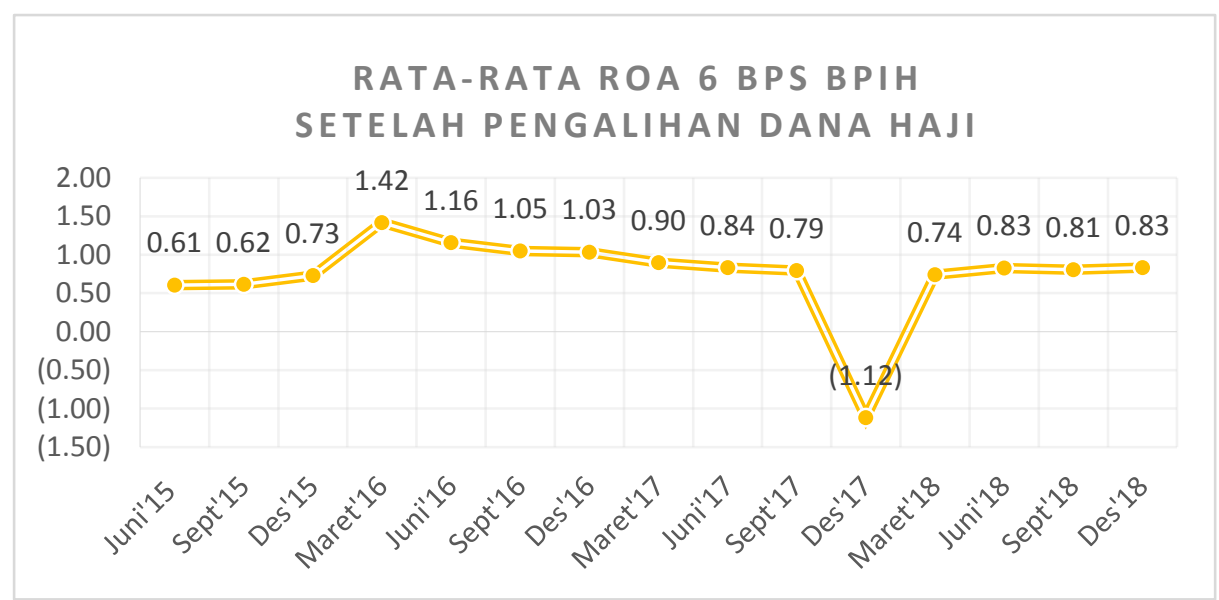

Gambar 9. Rata-rata ROA Setelah Pengalihan Dana Haji Sumber: Hasil Olah Data Penulis 2019

Berdasarkan grafik 9 diatas dapat diketahui bahwa di dalam perkembangan rata-rata Return On Assets (ROA) 6 bank syariah tersebut, terjadi kenaikan dari tahun 2015 hingga Maret 2016. Namun mengalami penurunan terus menerus hingga Desember 2017 mencapai nilai minimum yaitu -1,12, lalu mengalami kenaikan hingga tahun 2018.

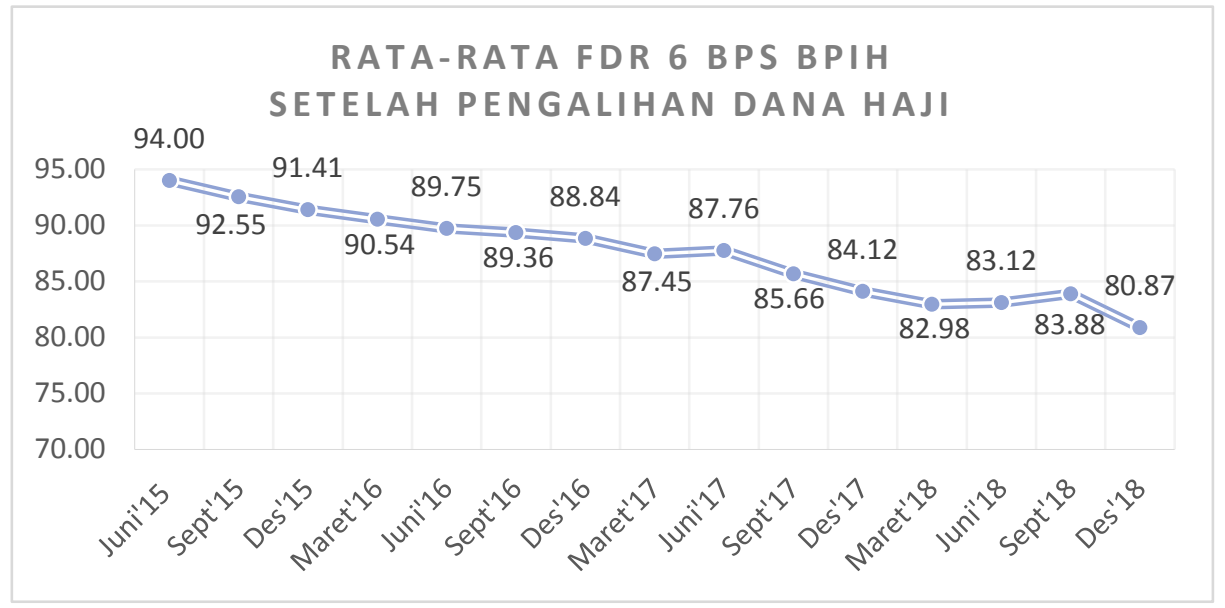

Gambar 10. Rata-rata FDR Setelah Pengalihan Dana Haji Sumber: Hasil Olah Data Penulis 2019

Berdasarkan tabel 10 diatas dapat diketahui bahwa di dalam perkembangan rata-rata Financing to Deposit Ratio (FDR) 6 bank syariah tersebut, selalu terjadi penurunan dari tahun 2015 hingga tahun 2018. Semakin tinggi rasio ini, semakin rendah kemampuan likuiditas bank sedangkan apabila rasio FDR menurun maka diindikasikan pembiayaan yang disalurkan oleh bank menurun dan dana yang berhasil dihimpun oleh bank belum bisa dikelola dengan optimal untuk segera disalurkan kepada masyarakat dalam bentuk pembiayaan.

\section{a. Kinerja Keuangan Sebelum Pengalihan Dana Haji PT Bank Syariah Mandiri}

Berikut disajikan grafik perkembangan dari masing-masing variabel penelitian selama periode pengamatan: 


\section{FDR SESUDAH PENGALIHAN DANA HAJI BANK SYARIAH MANDIRI}

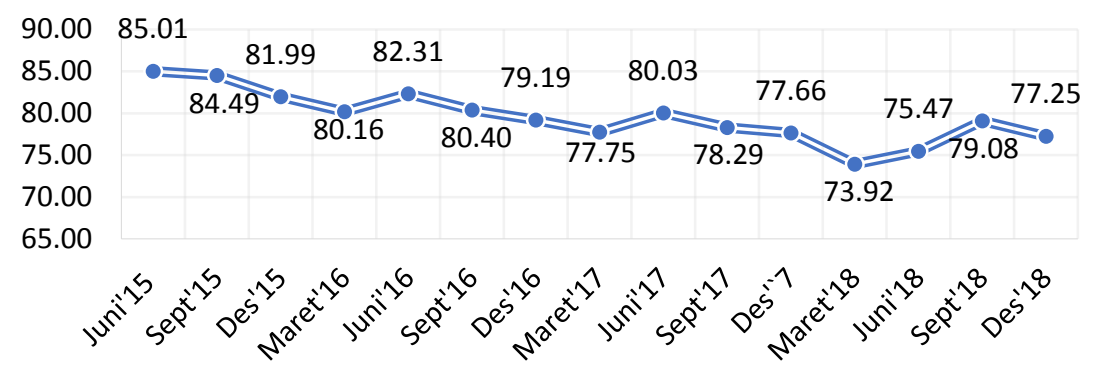

\section{ROA SETELAH PENGALIHAN DANA HAJI BANK SYARIAH MANDIRI}

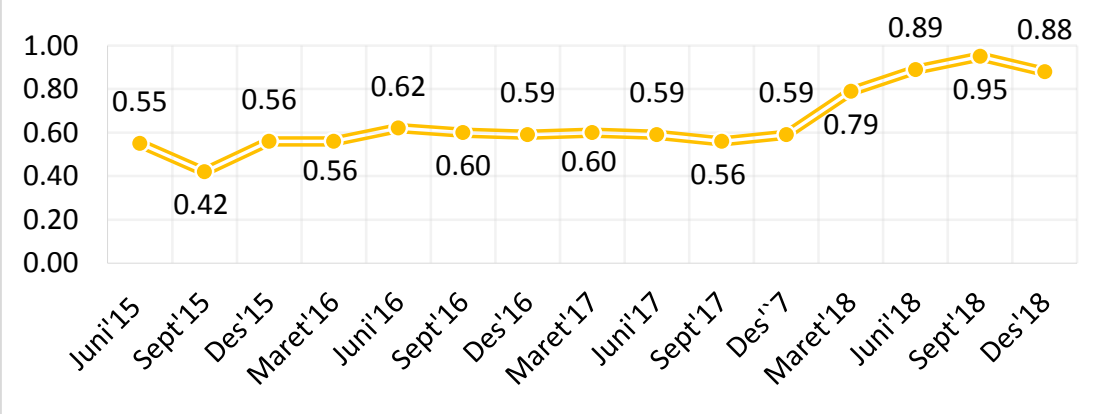

Gambar 11. Perkembangan ROA dan FDR Bank Syariah Mandiri Sumber: Hasil Olah Data Penulis 2019

\section{- Profitabilitas (Return On Assets)}

Dari grafik diatas terlihat bahwa ROA setelah pengalihan dana haji pada Bank Syariah Mandiri naik turun dari Juni 2015 hingga Desember 2015 lalu stagnan hingga Desember 2017 kemudian mengalami kenaikan hingga September 2018. Namun turun pada akhir Desember 2018. Apabila dilihat pada grafik 11, ROA Bank Syariah Mandiri cukup baik karena berada pada rentang 0,5\%-1,25\%. Jika dibandingkan dengan rata-rata ke 6 BPS BPIH yang ada pada yang ada pada grafik IV.12, Bank Syariah Mandiri berada di bawah rata-rata dari tahun Juni 2010 hingga September 2017. Kemudian pada Desember 2017 berada di atas rata-rata 6 BPS BPIH.

\section{- Likuiditas (Financing Deposit Ratio)}

Dari grafik diatas terlihat bahwa FDR sebelum pengalihan dana haji pada Bank Syariah Mandiri mengalami penurunan dari tahun 2015 hingga Maret 2016 lalu naik pada Juni 2016, namun harus turun kembali sampai Maret 2017. Naik kembali pada Juni 2017 dan mengalami penurunan hingga maret 2018 dan mengalami kenaikan sampai September 2018, namun harus turun kembali pada Desember 2018. Apabila diperhatikan pada grafik 11, tingkat FDR Bank Syariah Mandiri masih berada pada standar yang ditetapkan Bank Indonesia. Jika dilihat pada grafik 11 dibandingkan dengan rata-rata 6 BPS BPIH, Bank Syariah Mandiri selalu berada di bawah rata-rata 6 BPS BPIH.

\section{b. Kinerja Keuangan Setelah Pengalihan Dana Haji PT. Bank Rakyat Indonesia Syariah}

Berikut disajikan grafik perkembangan dari masing-masing variabel penelitian selama periode pengamatan: 


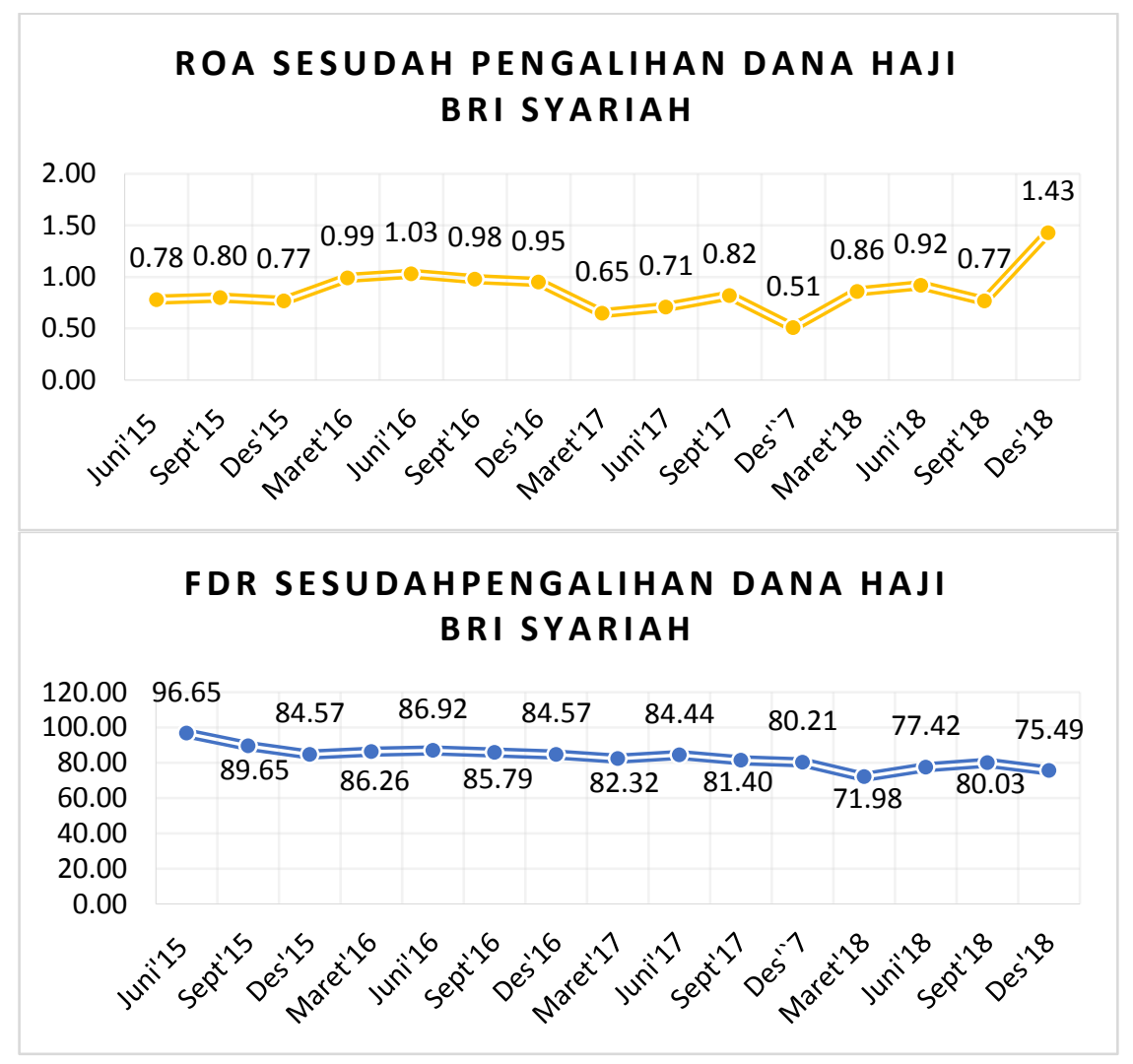

Gambar 12. Perkembangan ROA dan FDR BRI Syariah

Sumber: Hasil Olah Data Penulis 2019

\section{- Profitabilitas (Return On Assets)}

Dari grafik diatas terlihat bahwa ROA setelah pengalihan dana haji pada Bank Rakyat Indonesia Syariah naik turun dari Juni 2015 hingga September 2018 kemudian mengalami kenaikan yang cukup tinggi pada Desember 2018. Apabila dilihat pada grafik 12, ROA Bank Rakyat Indonesia Syariah cukup baik karena berada pada rentang 0,5\%-1,25\%. Jika dibandingkan dengan rata-rata ke enam BPS BPIH, Bank Rakyat Indonesia Syariah terkadang berada di atas rata-rata terkadang di bawah.

\section{- Likuiditas (Financing Deposit Ratio)}

Dari grafik diatas terlihat bahwa FDR setelah pengalihan dana haji pada Bank Rakyat Indonesia Syariah turun dari Juni 2015 hingga Desember 15 kemudian stagnan sampai Desember 2017, lalu naik turun hingga Desember 2018. Apabila diperhatikan pada grafik 12, tingkat FDR Bank Rakyat Indonesia Syariah sebagian triwulan masih berada pada standar yang ditetapkan Bank Indonesia, namun untuk sebagian triwulan lagi berada di bawah 78\%. Hal tersebut mencerminkan banyak dana yang menganggur dan tidak disalurkan dalam bentuk pembiayaan. Jika dilihat pada grafik IV.13, Bank Rakyat Indonesia Syariah selalu berada di bawah rata-rata 6 BPS BPIH.

\section{c. Kinerja Keuangan Setelah Pengalihan Dana Haji PT. Bank Negara Indonesia Syariah}

Berikut disajikan grafik perkembangan dari masing-masing variabel penelitian selama periode pengamatan: 


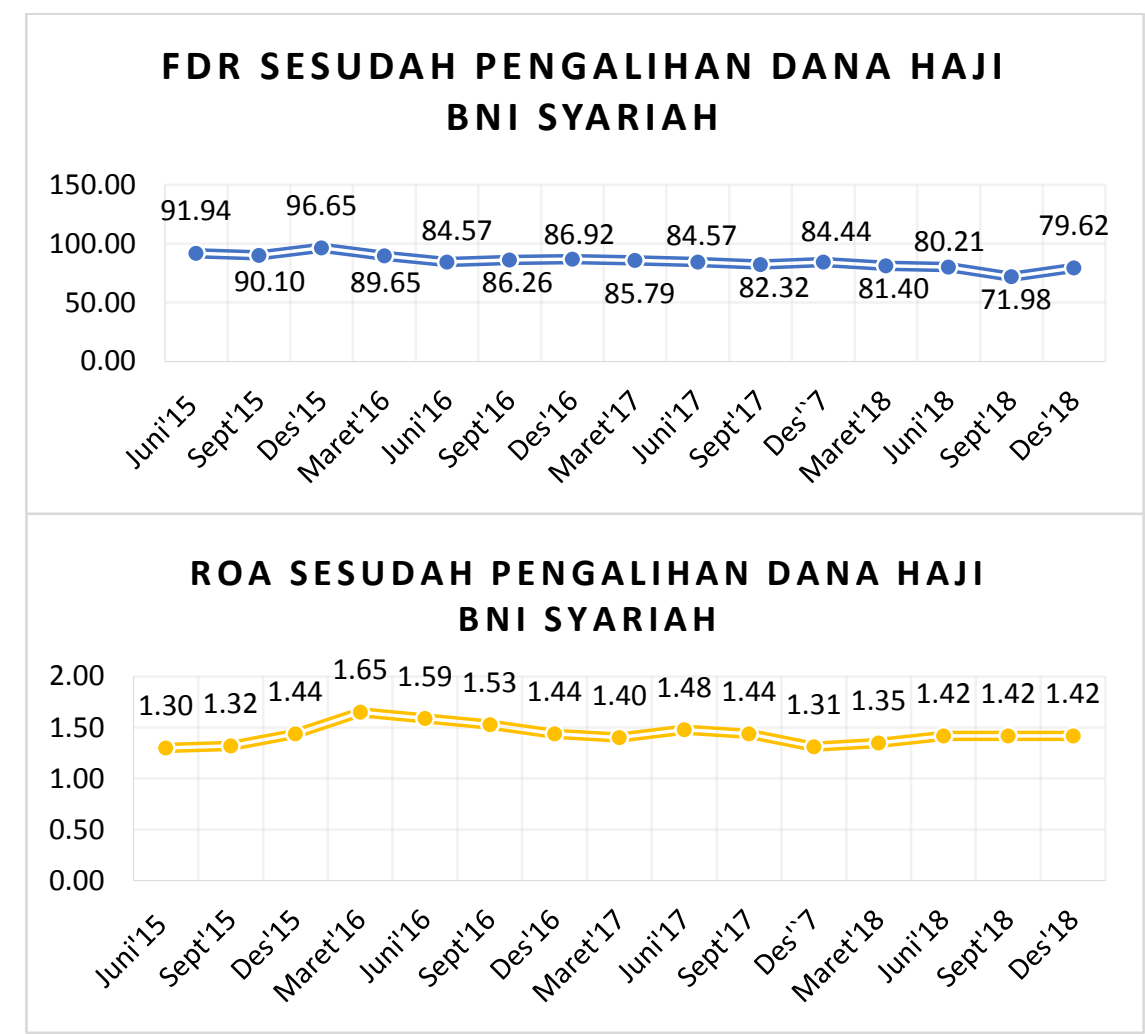

Gambar 13. Perkembangan ROA dan FDR BNI Syariah Sumber: Hasil Olah Data Penulis 2019

\section{- Profitabilitas (Return On Assets)}

Dari grafik diatas terlihat bahwa ROA setelah pengalihan dana haji pada Bank Negara Indonesia Syariah kenaikan dari Juni 2015 hingga Maret 2016. Kemudian mengalami penurunan hingga Maret 2017. Kemudian naik turun hingga tahun Juni 2018 dan stagnan pada 3 triwulan terakhir di tahun 2018. Apabila dilihat pada grafik 13, ROA Bank Negara Indonesia Syariah baik karena berada pada rentang 1,25\%-1,5\%. Jika dibandingkan dengan rata-rata ROA ke enam BPS BPIH, Bank Negara Indonesia Syariah selalu berada di atas rata-rata dari tahun 2015 hingga tahun 2018.

\section{- Likuiditas (Financing Deposit Ratio)}

Dari grafik diatas terlihat bahwa FDR sebelum pengalihan dana haji pada Bank Negara Indonesia Syariah naik turun dari tahun 2015 hingga Desember 2016, dan mengalami penurunan hingga September 2017, lalu naik turun hingga Desember 2018. Apabila diperhatikan pada grafik 13, tingkat FDR Bank Negara Indonesia Syariah sebagian besar triwulan masih berada pada standar yang ditetapkan Bank Indonesia, namun untuk triwulan September 2018 berada di bawah 78\%. Hal tersebut mencerminkan banyak dana yang menganggur dan tidak disalurkan dalam bentuk pembiayaan. Jika dilihat pada grafik IV.13, Bank Negara Indonesia Syariah berada di bawah rata-rata 6 BPS BPIH. Namun untuk triwulan Desember 2015 dan triwulan Desember 2017 berada di atas rata-rata rasio FDR 6 BPS BPIH.

\section{d. Kinerja Keuangan Setelah Pengalihan Dana Haji PT. Bank Mega Syariah}

Berikut disajikan grafik perkembangan dari masing-masing variabel penelitian selama periode pengamatan: 


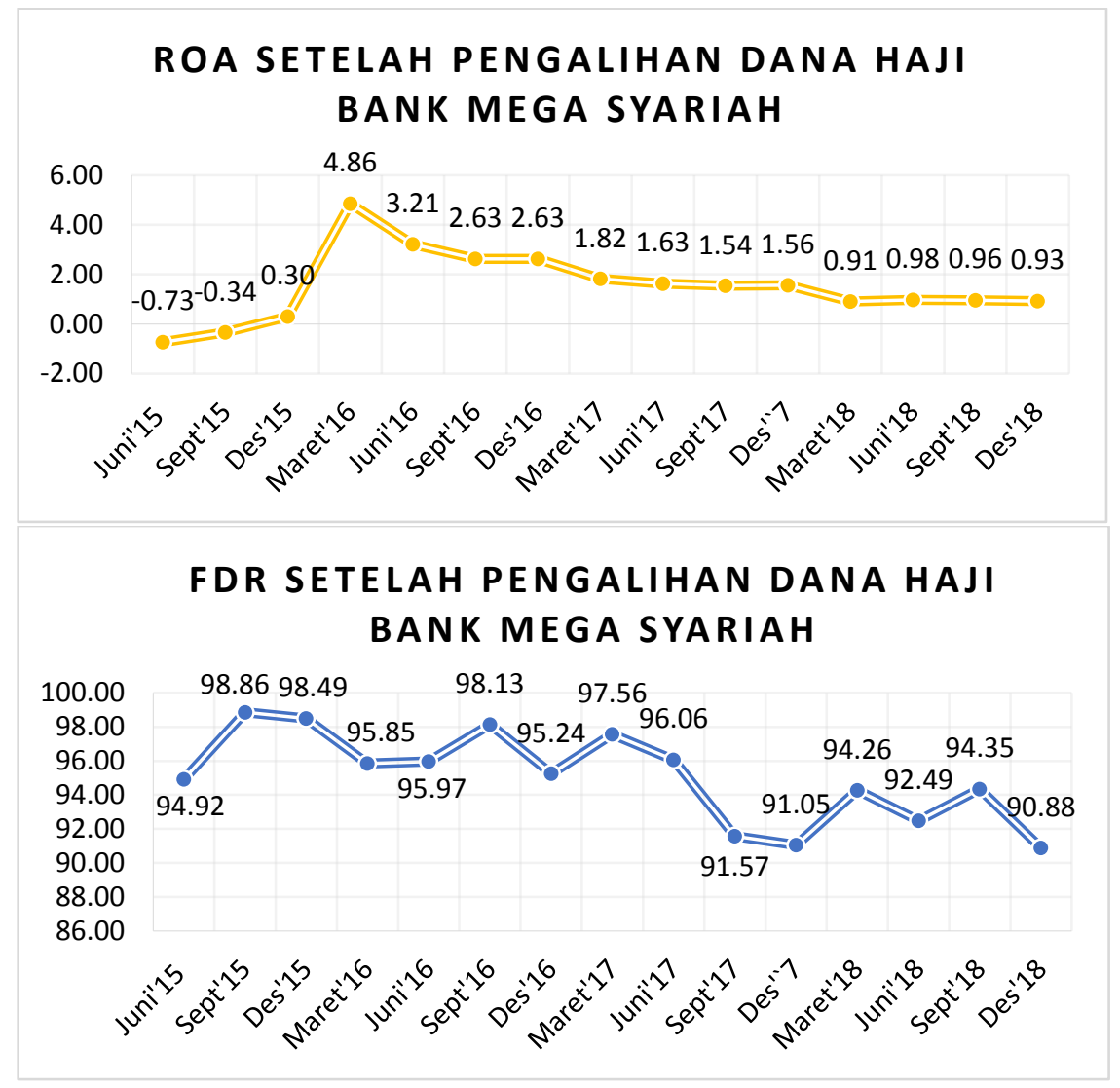

Gambar 14. Perkembangan ROA dan FDR Mega Syariah Sumber: Hasil Olah Data Penulis 2019

\section{- Profitabilitas (Return On Assets)}

Dari grafik diatas terlihat bahwa ROA setelah pengalihan dana haji pada Bank Mega Syariah mengalami kenaikan yang cukup tajam dari Juni 2015 hingga Maret 2016. Kenaikan FDR dari bulan Desember 2016 ke Maret 2016 cukup besar yaitu 4,56. Kemudian mengalami penurunan hingga Maret 2018. Kemudian stagnan sampai akhir tahun 2018. Apabila dilihat pada grafik 14, ROA Bank Mega Syariah untuk awal triwulan 2015 dalam kategori "tidak baik" karena $<0 \%$, hal tersebut membuat Bank Mega Syariah sangat sensitif terhadap pengaruh negatif kondisi yang dapat membahayakan kelangsungan usaha. Namun untuk triwulan berikutnya mengalami perkembangan ROA yang sangat baik. Walaupun harus turun kembali sampai Desember 2018. Jika dibandingkan dengan rata-rata ke enam BPS BPIH, Bank Mega Syariah berada di bawah rata-rata untuk tahun 2015 namun pada tahun 2016 hingga tahun 2018 berada di atas ratarata ke 6 BPS BPIH.

\section{- Likuiditas (Financing Deposit Ratio)}

Dari grafik diatas terlihat bahwa FDR sebelum pengalihan dana haji pada Bank Negara Indonesia Syariah naik turun dari tahun 2015 hingga Juni 2017, dan mengalami penurunan untuk 2 triwulan di tahun 2017, lalu naik turun kembali hingga Desember 2018. Apabila diperhatikan pada grafik 14, tingkat FDR Bank Mega Syariah berada pada standar yang ditetapkan Bank Indonesia. Jika dilihat pada grafik IV.13, Bank Mega Syariah selalu berada di atas rata-rata 6 BPS BPIH.

\section{e. Kinerja Keuangan Setelah Pengalihan Dana Haji PT. Bank Panin Dubai Syariah}

Berikut disajikan grafik perkembangan dari masing-masing variabel penelitian selama periode 
pengamatan:

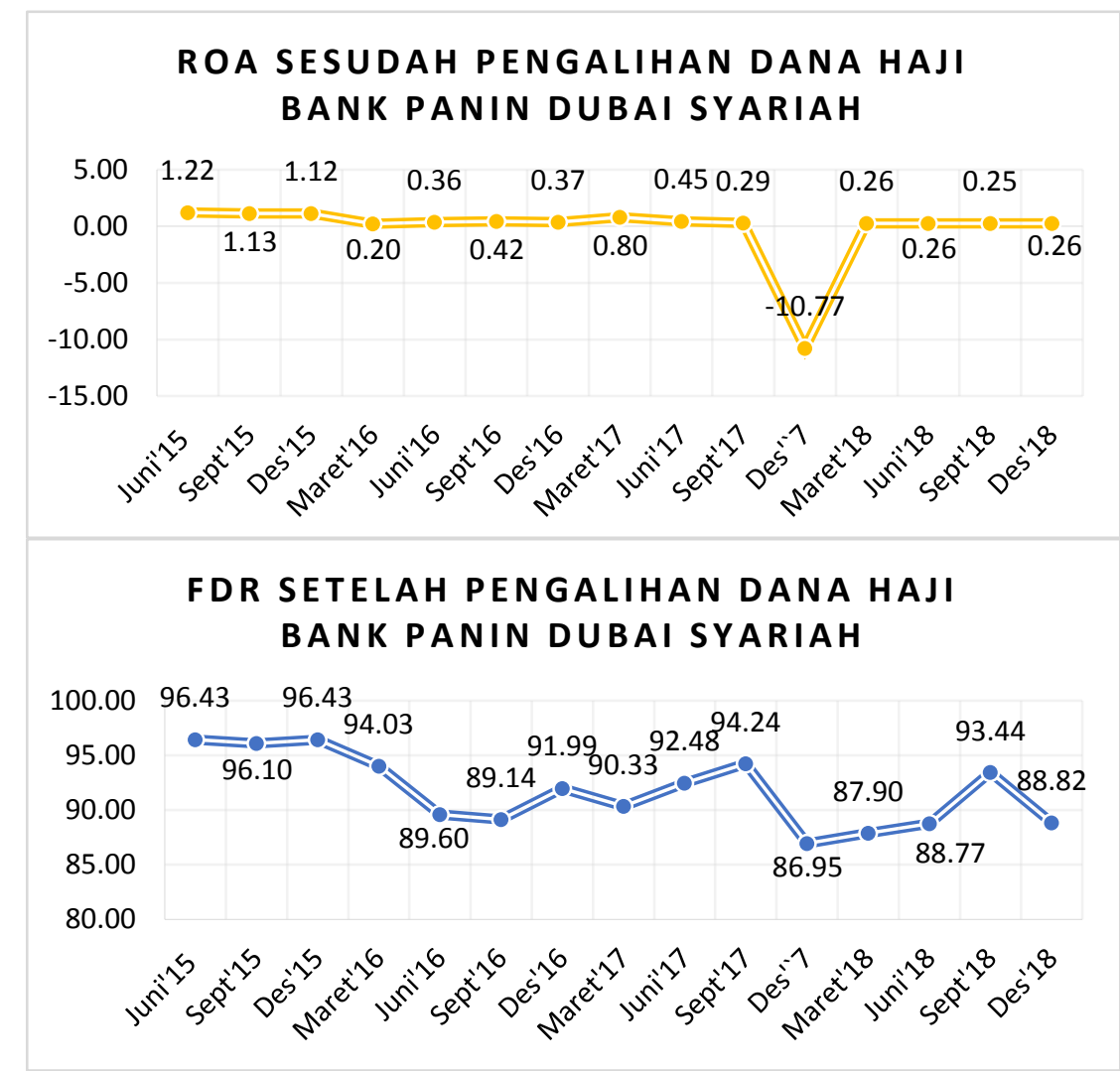

Gamvar 15. Perkembangan ROA dan FDR Bank Panin Dubai Syariah Sumber: Hasil Olah Data Penulis 2019

\section{- Profitabilitas (Return On Assets)}

Dari grafik diatas terlihat bahwa ROA setelah pengalihan dana haji pada Bank Panin Dubai Syariah stagnan hingga Desember 2017 lalu mengalami penurunan yang cukup tajam pada Desember 2017 hingga mencapai -10,77. Tidak lama dari itu mengalami kenaikan yang cukup tajam pula yaitu sebesar 10,51. Lalu stagnan sampai akhir tahun 2018. Apabila dilihat pada grafik 15, ROA mengalami penurunan hingga pada Desember 2017, karena nilai ROA $<0 \%$ Namun untuk triwulan berikutnya mengalami perkembangan ROA yang cukup baik.

\section{- Likuiditas (Financing Deposit Ratio)}

Dari grafik diatas terlihat bahwa FDR sebelum pengalihan dana haji pada Bank Panin Dubai Syariah penurunan dari tahun 2015 hingga September 2016, lalu naik turun hingga Maret 2017. Kemudian naik sampai September 2017, lalu naik turun kembali hingga Desember 2018. Apabila diperhatikan pada grafik 15, tingkat FDR berada pada standar yang ditetapkan Bank Indonesia.

\section{f. Kinerja Keuangan Setelah Pengalihan Dana Haji PT. Bank Muamalat}

Berikut disajikan grafik perkembangan dari masing-masing variabel penelitian selama periode pengamatan: 


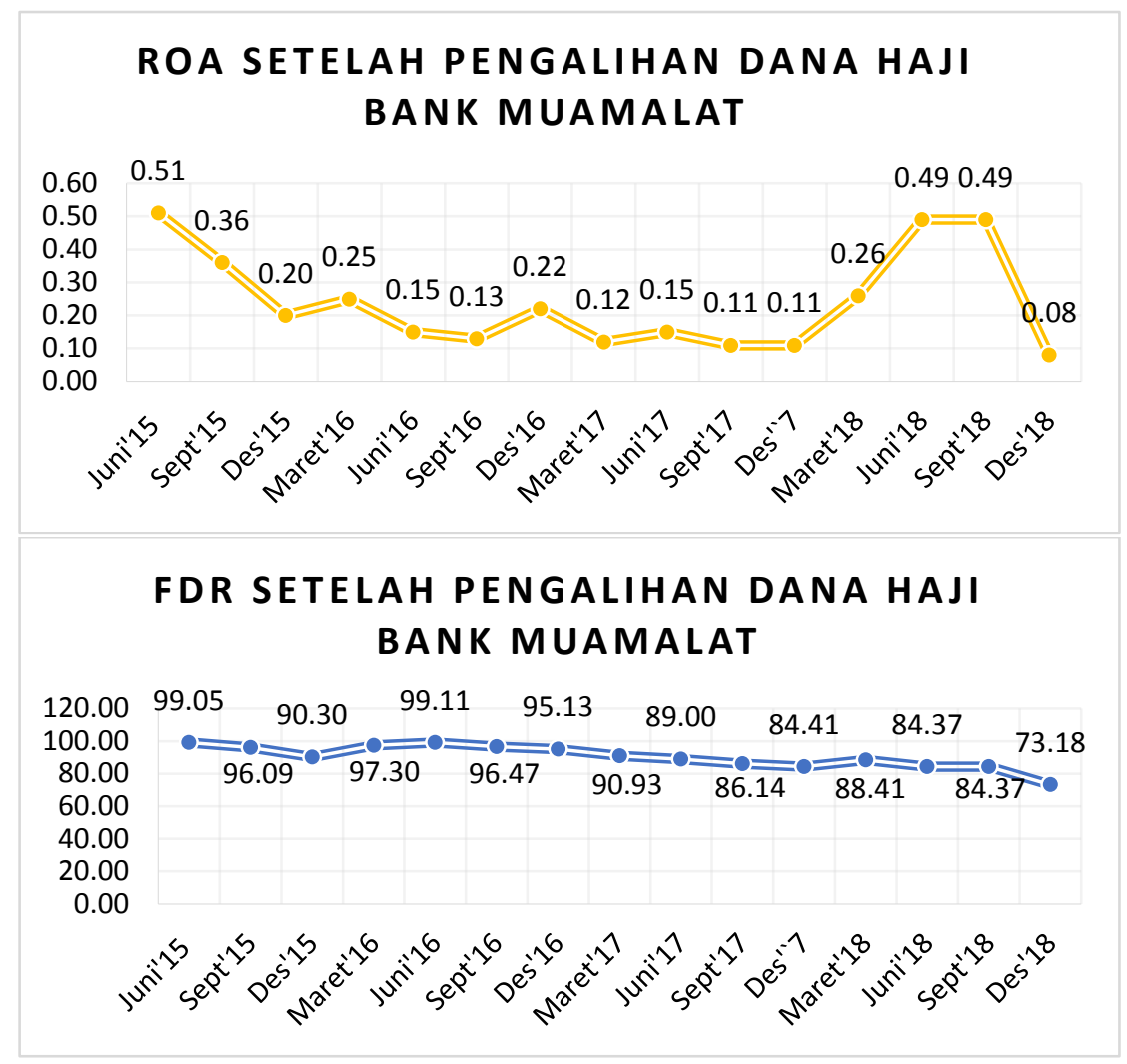

Gambar 16. Perkembangan ROA dan FDR Bank Muamalat Sumber: Hasil Olah Data Penulis 2019

\section{- Profitabilitas (Return On Assets)}

Dari grafik diatas terlihat bahwa ROA setelah pengalihan dana haji pada Bank Muamalat mengalami penurunan dari Juni 2015 hingga Desember 2015 lalu naik turun hingga Desember 2017 kemudian mengalami kenaikan yang cukup tajam hingga Juni 2018 stagnan hingga September 2018 dan akhirnya mengalami penurunan di akhir tahun 2018. Apabila dilihat pada grafik 16, ROA Bank Muamalat kurang baik karena berada pada rentang $0 \%-0,5 \%$. Jika dibandingkan dengan rata-rata ROA ke 6 BPS BPIH, Bank Muamalat cenderung berada di bawah rata-rata kecuali pada Desember 2017 berada di atas rata-rata 6 BPS BPIH.

\section{- Likuiditas (Financing Deposit Ratio)}

Dari grafik diatas terlihat bahwa FDR sebelum pengalihan dana haji pada Bank Muamalat Mandiri mengalami penurunan dari tahun 2015 hingga Juni 2016 dan mengalami penurunan hingga Desember 2017 kemudian naik turun kembali hingga Desember 2018. Apabila diperhatikan pada grafik 16, tingkat FDR Bank Muamalat sebagian besar triwulan masih berada pada standar yang ditetapkan Bank Indonesia, namun untuk triwulan Desember 2018 berada di bawah 78\%. Jika dilihat pada grafik dibandingkan dengan rata-rata 6 BPS BPIH, Bank Muamalat cenderung berada di atas rata-rata kecuali pada Desember 2018 berada di bawah rata-rata rasio FDR 6 BPS BPIH.

\subsection{Pengujian Hipotesis}

Berdasarkan hasil uji normalitas data yang menghasilkan bahwa data tidak berdistribusi normal, maka pengujian hipotesis dilakukan menggunakan uji beda statistik non parametrik yaitu uji beda Wilcoxon Signed Rank Test dikarenakan data tidak berdistribusi normal. Pengujian 
hipotesis ini menggunakan bantuan program SPSS 20 for Windows. Hasil uji hipotesis ini adalah sebagai berikut:

Tabel 3. Hasil Uji Wilcoxon Signed Rank Test pada 6 Bank Umum Syariah Sebelum dan Setelah Pengalihan Dana Haji pada Bank Syariah

\begin{tabular}{|l|r|r|}
\hline \multicolumn{1}{|c|}{ Test Statistics $^{\mathbf{b}}$} \\
& $\begin{array}{l}\text { ROA Setelah - } \\
\text { ROA Sebelum }\end{array}$ & $\begin{array}{r}\text { FDR Setelah - } \\
\text { FDR Sebelum }\end{array}$ \\
\hline$Z$ & $-4,334^{\mathrm{a}}$ & $-4,283^{\mathrm{a}}$ \\
Asymp. Sig. (2-tailed) &, 000 &, 000 \\
\hline
\end{tabular}

a. Based on positive ranks.

b. Wilcoxon Signed Ranks Test

Sumber: Hasil Olah Data SPSS 2019

Hasil uji beda wilcoxon signed ranks test terhadap nilai ROA dan FDR pada 6 Bank Umum Syariah menunjukan bahwa tingkat signifikansi sebesar 0,000 . Oleh karena tingkat signifikansi sebesar $0,000<0,05$, maka dapat disimpulkan bahwa terdapat perbedaan yang signifikan antara ROA dan FDR sebelum dan setelah pengalihan dana haji pada 6 Bank Umum Syariah.

\section{Penutup}

Hasil penelitian ini menunjukkan bahwa dana haji yang dialihkan ke perbankan syariah dapat memberikan dampak positif melalui suntikan dana pihak ketiga. Namun hal tersebut tidak serta merta langsung berdampak positif bagi kinerja keuangan bank syariah. Walaupun kinerja keuangan mengalami penurunan setelah adanya pengalihan dana haji, dana haji tetap diperlukan bagi bank syariah karena dana haji merupakan dana murah yang bagi hasilnya sebesar $6 \%$ dengan penempatan yang lama. Dengan komposisi dana yang kuat, murah dan tenor panjang dapat dijadikan Bank syariah sebagai modal untuk melakukan pembiayaan yang kuat dan berkualitas. Maka dari itu saran praktis yang dapat diberikan.

Perbankan syariah harus meningkatkan skill SDM agar unggul yaitu SDM yang paham akan pembiayaan, potensi bisnis, dan paham akan pengaturan Asset and Liability Manajement (ALMA) agar dana haji tidak mengendap dan bisa dioptimalkan menjadi pendapatan. Sebab apabila dana haji mengendap nantinya akan timbul biaya dana yang mahal yang berdampak pada keterbatasan segmen pembiayaan.

Selanjutnya Bank Syariah harus meningkatkan modal banknya sendiri karena perbankan syariah fokus pada segmen ritel, yaitu UMKM dan konsumtif. Dimana pada segmen tersebut memerlukan dukungan infrastruktur berupa jaringan kantor, ATM/POS yang luas, dan teknologi informasi yang handal, agar bank syariah lebih leluasa mengembangkan bisnis dan pembiayaannya.

\section{Daftar Pustaka}

AlQur'an dan terjemabnya. (t.thn.). CP penerbit Dipenogoro.

Arini, T. I. (2017). Profitabilitas Sebelum Dan Sesudah Pengaliban Dana Haji Dari Bank Konvensional Ke Bank Syariah Periode 2011-2016 (Studi Kasus Di Bank Syariah Mandiri). Bandung: Politeknik Negeri Bandung.

Bank Syariah Mandiri. (2014). Annual Report Bank Syariah Mandiri 2014.

BPKH Gelontorkan Dana Rp 175 Untuk Program Kemaslahatan Umat. (2018). Diambil kembali dari Tribun News: http://www.tribunnews. com/nasional/2018/10/19/bpkh-gelontorkan- 
dana-rp-175-untuk-program-kemaslahatan-umat. [Diakses 14 November 2018 3:20]

Budiman, M. A. (2016). Analisis Faktor Yang Mempengaruhi Biaya Penyelenggaraan Ibadah Haji di Indonesia. Jurnal Hukum Islam, 1-14.

Cahyono, E. F. (2017). Impact of Government Policy on Hajj Funds Transfer on Conventional Bank and Islamic Bank Third Party Funds inIndonesia: Difference in Difference Approach. SCITEPRESS - Science and Technology, 176-180.

CIA World Factbook. (2017). Diambil kembali dari https:/www.cia.gov/library/publications/theworld-factbook/geos/id.html [Diakses : 14 September 2018 13:17]

Fitriyadi, F. (2015). Analisis Pengaliban Dana Haji dari Bank Konvensional ke Bank Syariah terbadap Pertumbuhan Dana Pihak Ketiga (DPK) dan Penurunan Financing To Deposit Rasio (FDR): (Studi Kasus Bank Syariah Mandiri Banda Aceb. Banda Aceh: Fakultas Ekonomi dan Bisnis, Universitas Syiah Kuala Darussalam.

Hijriyani, N. Z., \& Setiawan, S. (2017). Analisis Profitabilitas Perbankan Syariah di Indonesia sebagai Dampak Dari Efisiensi Operasional. Jurnal Kajian Akuntansi, 1(2), 194-209

Hidayat, R. (2014). Pengelolaan Dana Haji. (hal. Vol 6 Hal 2). Jakarta Timur: Pusat Dokumentasi dan Jaringan Informasi Hukum Nasional.

Indriyani, R. (2017). Analisis Komparatif Discretionary Accrual sebagai Pendeteksi Manajemen Laba pada Bank Umum Syariah di Indonesia Sebelum dan Sesudah Implementasi Konvergensi IFRS. Bandung: Politeknik Negeri Bandung.

Juni 2014, Dana Haji Rp 16 triliun harus pindab ke Bank Syariah. (2014, Maret). Diambil kembali dari Detik Finance: https://m.detik.com/finance/moneter/d-2536437/juni-2014-Dana-HajiRp-16-triliun-harus-pindah-ke-bank-syariah [Diakses 7 Oktober 2018]

Kelola Dana Haji BPKH Gandeng 31 Bank. (2018). Diambil kembali dari Tempo.co: https:// nasional.tempo.co/read/1065273/kelola-dana-haji-bpkh-gandeng-31-bank.

[Diakses 14 November 2018 3:20]

Lukman Hakim Saifuddin: Manfaat Investasi Dana Haji Untuk. Umat. (2017). Diambil kembali dari Raya Berita: https://rayaberita.wordpress.com/2017/08 /06manfaat-investasi-dana-haji- untukumat/ [Diakses 14 November 2018 3:20]

Munawir. (2014). Analisa Laporan Kenangan. Yogyakarta: Liberty Yogyakarta.

Muslikhati., T. U. (2018). Analisis Perbandingan Penghimpunan Dana Pibak Ketiga Bank Syariab Sebelum dan Sesudah Kebijakan Tax Amnesty. Malang: Fakultas Agama Islam, Universitas Muhammadiyah Malang.

Nidjam, A. (2017). Akuntabilitas Informasi Biaya Penyelenggaraan Haji. (hal. Vol 14). I: Pusdiklat Tenaga Administrasi Kemenag RI .

Pengelolaan Dana Haji dan Rencana Strategis. (2017). (hal. 6-8). Jakarta: BPKH.

Peraturan Menteri Agama Republik Indonesia Nomor 30 Tabun 2013 tentang BPS BPIH. (2013 ). Jakarta: Menteri Agama.

Peraturan Menteri Agama No. 6 Tabun 2010 Pasal 5 ayat 1. (2010). Jakarta: Menteri Agama.

Peraturan Pemerintab RI No 5 tabun 2018 Pelaksanaan UU Pengelolaan Keuangan Haji. (2018). Jakarta: Menteri Agama.

Radio Republik Indonesia. (2017, Agustus 27). Menjawab Kontroversi Dana Haji Untuk Investasi. Surabaya, Indonesia.

Rossiana, G. (2018, Mei). Ada Pelunasan Haji, Dana Masyarakat di Bank Syariah Terkuras. Diambil kembali dari CNBC INDONESIA: 
https://www.cnbcindonesia.com/syariah/20180530192655-29-17243/ada-pelunasan-hajidana-masyarakat-di-bank-syariah-terkuras

Saifuddin, L. H. (2017). Manfaat Investasi Dana Haji Untuk Umat. Diambil kembali dari Raya Berita: https://rayaberita.wordpress.com/2017/08 /06manfaat-investasi-dana-haji- untuk-umat/ [Diakses 14 November 2018 3:20]

Septiana, N. I. (2015). Kontruksi Model Pengelolaan Kenangan Haji Pada Bank Syariah Di Indonesia. Yogyakarta: Magister Ilmu Ekonomi Islam, Universitas Islam Negeri Sunan Kalijaga.

Setiawan, S \& Ratna Maya Sari. (2018). Rentabilitas Bank Umum Syariah Sesudah Spin Off Berdasarkan Tipe Pemisahannya Di Indonesia. Amwaluna, Vol 2 No 1.

Siaran Pers Bersama. (2017). Manfaat Investasi Dana Haji Untuk Umat. Menteri Agama.

Siregar, S. (2015). Metode Penelitian Kuantitatif, Cetakan ke-3. Jakarta: PRENAMEDIA GROUP.

Sugiyono. (2009). Metode Penelitian Kuantitatif kualitatif dan R\&D, Cetakan ke-7. Bandung: CV Alfabeta.

Sugiyono. (2012). Metode Penelitian Kuantitatif kualitatif dan R\&D, Cetakan ke-7. Bandung: CV Alfabeta.

Wahyu, D. R. (t.thn.). Financing To Deposit Ratio (Fdr) Sebagai Salab Satu Penilaian Kesehatan Bank Umum Syariah (Study Kasus Pada Bank BJB Syariah Cabang Serang). Banten: IAIN Sultan Maulana Hasanuddin Banten.

Wijayanti, A. (2018). Analisis Komparatif Tingkat Kesehatan Sebelum dan Setelah Penerapan Linkage Program Menggunakan Metode Risk Profile, Good Corporate Governance, Earnings and Capital(RGEC) Periode 2011-2017 (Studi Kasus PT. BPRS Baiturridha Pusaka Kantor Pusat. Bandung: Politeknik Negeri Bandung.

Zubaedi. (2016). Analisis Problematika Manajemen Pelaksanaan Haji Indonesia Restrukturisasi Model Pengelolaan Haji Menuju Manajemen Haji Yang Modern. Manhaj, Vol 4 No 3. 